\title{
REFERENCE
}

NBSIR 84-2959

\section{Corrosion of Materials Used in Steam Generating Boiler Systems}

\author{
E. Escalante \\ D. Mathews \\ J. Fink
}

U.S. DEPARTMENT OF COMMERCE

National Bureau of Standards

Center for Materials Science

Metallurgy Division

Gaithersburg,MD 20899

October 1984

Final Report

Prepared for

U.S. Department of Energy

QC

1000 Independence Avenue, SW

100

Washington, DC 20585 



\section{CORROSION OF MATERIALS USED IN STEAM GENERATING BOILER SYSTEMS}
E. Escalante
D. Mathews
J. Fink

U.S. DEPARTMENT OF COMMERCE

National Bureau of Standards

Center for Materials Science

Metallurgy Division

Gaithersburg, MD 20899

October 1984

Final Report

Prepared for

U.S. Department of Energy

1000 Independence Avenue, SW

Washington, DC 20585

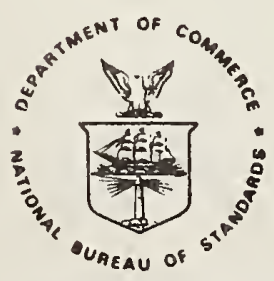

U.S. DEPARTMENT OF COMMERCE, Malcolm Baldrige, Secretary NATIONAL BUREAU OF STANDARDS, Ernest Ambler, Director 

Corrosion of Materials Used in

Steam Generating Boiler Systems

By

E. Escalante, D. Mathews, J. Fink
National Bureau of Standards
Gaithersburg, MD 20899

\begin{abstract}
Five alloys, SA178, SA192, SA213-T11, SA213-T22, and Type 304 Stainless Steel, were evaluated on their resistance to pitting in a coal burning boller and in a residential refuse burning incinerator. The materials were introduced into the vicinity of the boiler tubes using a probe whose temperature was controlled and monitored to simulate conditions of the boiler tubes. After three to six months, the probes were withdrawn and the alloy specimens removed for evaluation. The data indicate that the environment of the refuse burning incinerator was considerably more aggressive than that of the coal burning boiler. Chloride was found in practically all the pits examined in the alloys from the refuse burning system, but no chloride was found in the pits examined on the materials exposed in the coal burning boiler. The data suggest that the moisture from lawn clippings increases the rate of attack which is further agsravated by large temperature fluctuations. Type 304 stainless steel was the most resistant to pitting in both environments, but the SA213-T11 and SA213-T22 were less resistant to pitting than the lower alloy SA178 and SA192 in the refuse burning incinerator.
\end{abstract}


Corrosion of Materials Used in

Steam Generating Boller Systems

E. Escalante, D. Mathews, J. Fink

National Bureau of Standards

Gaithersburg, MD 20899

With the need for new sources of energy, many alternatives to petroleum base fuels have been examined. One such alternative is the use of Municipal Solid Waste (MSW) as a fuel to fire steam generating plants. This apporach offers the attraction of reducing the bulk of the waste generated by cities and towns to a manageable level while at the same time supplying steam for the production of electrical power for these same municipalities $(1,2)$. While the advantages are obvious, there is at least one problem under study, and it is the increased rate of deterioration of the steam generating plant resulting from the corrosive byproducts of combustion of the MSW $(3,4,5)$. It is this facet, corrosion of heat exchange tubes, that is the subject of this paper.

\section{Experimental Approach}

A search through the literature (Bibliography - Appendix A) revealed that corrosion studies, in general, have focused on metal wastage in terms of weight loss. However, it was noted that often times the fallure mode in the heat exchange tubes was through pitting rather than through general corrosion. Thus, it was decided that this study should look more carefully at this mode of attack.

Because if was desirable to examine the performance of several alloys in the incinerator gas stream, a probe to be inserted into the incinerator was chosen as a means of introducing metal coupons to the environment $(6,7,8)$. This approach offers several attractive features such as: 1) Ease of placement and removal of probe without affecting the operation of the incinerator; 2) the ability to replace coupons on the probe at intervals of time; and 3 ) required a minimum of modification to the incinerator system for use of the probe.

Two steam generating plants were included in this study. The first plant, a coal fired system, was the Wright Patterson Air Force Base Boiler Station (WPAFB Facility) located in Dayton, Ohio. The second, and the one of most interest, is the NASA Langley Refuse Fired Steam Generating Facility (N/L Facility) located in Hampton, Virginia.

The probe was designed so that four sets of five different alloys (20 coupons) could be exposed at one time. Figure 1 illustrates the basic design of the probe, and shows the location of the four thermocouples along the length of the probe at the surface of four coupons. The temperature was maintained below a preset maximum as sensed by the thermocouple nearest the end of the probe monitored by a controller actuating an air valve that allowed forced air through the probe as needed. In addition, the velocity of the air varied along the length of the probe as determined by the cross section of the air passage between 
the inside wall of the coupons and the constrictor illustrated. Thus, the temperature increased towards the tip of the probe with a temperature differential of apporximately $260^{\circ} \mathrm{C}\left(500^{\circ} \mathrm{F}\right)$ from one end to the other.

Characterization of the environment was done by periodically taking gas samples in the vicinity of the probe, and recording the temperatures of the four thermocouples on the probe every six hours. After a three to six month exposure, the probe was withdrawn from the incinerator and the coupons removed for examination. This examination consisted of mounting and polishing a portion of each coupon so that the cross section of the coupon with residue could be examined and chemically analyzed using electron probe microanalysis techniques. The remaining portion of each coupon was chemically cleaned, rinsed, dried, followed by pit depth measurements.

The chemical compositions of the five boiler pressure tubing alloys studied are listed in Table 1. The first two steels listed, SA178 and SA192, are low carbon steels, and the remaining three are two low alloy steels and a stainless steel. All are commercially available materials.

Measurements

Four $0.3 \mathrm{~mm}(0.012$ inch) diameter shielded chromel-alumel thermocouples were placed along the length of the probe and at the surface of four coupons. The temperature was measured and recorded at each thermocouple every six hours using a Doric Minitrend Data Logger. As mentioned earlier, the cross section of the air path in the probe varied along the length of the probe, and the cross sectional area of the air path increased by a factor of 5.5 from one end to the tip of the prode. It was this local rate of air flow within the coupons that determined the temperature along the probe. The maximum temperature of the probe was controlled by monitoring the temperature of the thermocouple nearest the tip. Thus, as the temperature of the thermocouple approached a preset maximum, the rate of air flow through the probe increased. This air flow regulation was achieved using a diaphram value operated by a Leeds \& Northrup Electromax $V$ controller.

A fine, machined surface finish was used for the coupons. The surface of several coupons was characterized using a Perthen S5P Profilometer prior to exposure. After approximately six months, the probe was withdrawn from the incinerator environment and the coupons removed for examination. In some cases the encrustation on the coupons was fragile, and it was necessary to coat the coupons with a thin layer of epoxy so that they could be handled without destroying the encrusted combustion product. once protected, a $3 / 8$ inch $(1 \mathrm{~cm})$ wide $r i n g$ was cut from each coupon and cleaned in passivated hydrochloric acid. The profilometer was then used to characterize this cleaned surface by measuring the depth of pltting. Pit depth measurements were made using a profilometer having a $10 \mathrm{um}$ $(0.4 \mathrm{mil})$ probe tip, and the maximum pit depth is reported. The cross section of the remaining portion of the coupon was examined with a low power microscope so that interesting features or pits could be ident1fled for further study with an ETEC Autoscan scanning electron microscope. Specific areas of interest were then analyzed using a Tracor Northern 
TN-2000 X-ray spectrum analyzer (Energy Dispersive X-ray Spectroscope) allowing identification of the chemical components under the electron beam. Through repeated metallographic polishing of the surface, the profile at various depths was examined in detail. The surfaces of the coupons taken from the second probe at the NASA/Langley Facility were examined by looking directly at the surface of the specimen, and then mechanically removing the oxide and looking at the metal underneath. In this way we avoided introducing contaminents or dissolving out soluble constituents during preparation.

Six incinerator gas samples were taken once every three months. This sampling was done every four hours over a 24-hour period. These samples were taken using an evacuated one liter glass flask connected through a glass stop cock to a $5 \mathrm{~mm}$ ID stainless steel tube $1 \mathrm{~m}$ long. The tube was inserted into the incinerator in the vicinity of the probe, and once in in place, the stop cock was simply opened allowing the incinerator gases to be drawn into the flask. The flask was then resealed and brought back to the laboratory for analysis using an Infrared Spectrophotometer and a Mass Spectrometer/Gas Chromatograph.

Results and Data

First, the results will be described for each of the two steam generating plants, then in the discussion the results will be combined and compared.

BOILER SYSTEM - The first probe, WPAFB Probe I, was placed in the boller tube environment of the coal burning plant at the WPAFB Facility where it remained for six months. The results of the spectrophotometric analysis of the sampled gases reveal that the bulk of the gas, excluding nitrogen gas, is carbon dioxide as illustrated in Figures 2 and 3 . These two rigures cover the portion of the spectrum that characterizes the carbon dioxide molecule. A mass spectrometer was then used to identify low concentration components of the gas. Figure 4 is typical of the display of the mass spectrometer data with mass units on the abscissa and relative intensity of concentration on the ordinate. Thus, from this figure, mass numbers 28,32 , and 44 represent nitrogen, oxygen, and carbon dioxide. Nitrogen, a major component of the alr forced into the combustion chamber, is also discernible at mass 14. Sulphur (mass 32), a known contaminant of coal, is present in small concentrations but is overshadowed by the oxygen peak. Except for the presence of sulphur and water vapor, the gaseous products of coal combustion are relatively free of constituents that could have a strong influence on the corrosion of the boiler tubes.

The temperature data taken on WPAFB Probe I are shown in Figure 5 in which the temperature at the end of the probe (thermocouple 01) is plotted as a function of time. The most obvious feature of this plot is the amount of time the system spent below its operating temperature. In fact, the temperature was below $425^{\circ} \mathrm{C}\left(800^{\circ} \mathrm{F}\right)$ for $33 \%$ of the 160 days that the measurements were made. However, these temperature excursions occurred only on eight occasions, and lasted from a few hours to over two weeks.

Examination of the cross sectional surface of the specimens revealed that the encrustation was anywhere from less than $1 \mathrm{mil}(.04 \mathrm{~mm})$ to more than ( $3 \mathrm{~mm}$ ) $0.125 \mathrm{in}$. thick, and was always thicker on the down stream side of the coupon. When viewed with a low power microscope, it was evident that 
though the surfaces of the five materials were generally etched, the overall degree of attack was slight. Figure 6 is a photograph of one of the more severe pits on the SA213-T11 alloy which also shows the encrusted material above the pit. Examination with the scanning electron microscope revealed greater detail of the make up of this encrustation as seen in Figure 7. In this photograph, distinct layering with suspended particles in the matrix is visible, and is typical of the substance found on the coupon surfaces. The X-ray spectrograph of this encrusted matter ldentifles the chemical components as illustrated in Figure 8 . Iron (FE) is the major constituent followed by silicon (SI) from the silicon carbide refractory on the walls of the boiler, and aluminum (AL) from the aluminum oxide cement that binds the refractory material together are all clearly visible on the spectrum. Sulphur (S), a contaminent of coal, calcium (CA), titanium (TI), phosphorus (P), and arsenic (AS) are all present in lower concentrations. A spectrograph of the alloy is shown in Figure 9, and indicates the presence of iron (FE), chromium (CR), and silicon (SI) as expected.

The maximum pit depth data after six months of exposure are shown on Figure 10, and illustrate the degree of pitting at the four positions along the probe for each of the alloys. These data show that the 304 stainless steel, in general, developed less pitting attack that the other four materials, and that the SA213-T22 ferritic steel underwent the most severe attack. The effect of temperature or position on the probe was not as large as expected. In fact, the degree of pitting for the 304 stainless steel remained $10 \mathrm{~W}$ and almost constant for all temperatures. SA178, however, showed an increase in pitting resistance as the temperature increased to $490^{\circ} \mathrm{C}\left(910^{\circ} \mathrm{F}\right)$ toward the end of the probe. Based on these data and the deepest pit found for each material, a rate of pit growth was calculated for each material as listed in Table 2. The highest rate of pit growth found for any of the alloys at the WPAFB coal burning facility was $191 \mathrm{um} / \mathrm{yr}(7.5 \mathrm{mils} / \mathrm{yr})$ for the SA213-T22, and the lowest rate of pit growth was $99 \mathrm{um} / \mathrm{yr}(3.9 \mathrm{mils} / \mathrm{yr})$ for 304 stainless steel.

INCINERATOR SYSTEM - Three probes were exposed at the NASA/Langley Incinerator Facility, N/L Probe I, N/L Probe II, and N/L Probe III. The first two probes were each exposed for six months, and N/L Probe III was exposed for three months. The gaseous products of combustion from the $\mathrm{N} / \mathrm{L}$ refuse burning facility were expected to be considerably different from those sampled from the WPAFB coal burning facility, but in neither case did the spectrophotometer analysis show anything more than carbon dioxide. A more detailed examination of this refuse derived combustion gas using the mass spectrometer showed peaks as mass units $14,16,28,29,32$, and 44 as illustrated in Figure 11. Identification of the peaks revealed the presence of nitrogen, oxygen, carbon inonoxide, organics, and carbon dioxide. The peak at mass 29 is more difficult to identify with certainty since it could be any one of a number of possibilities, but since organics are in abundance in the refuse, it is not unreasonable to expect some indication of their existance in the spectrographic analysis. Thus, it is very probable that mass 29 represents some fragment of an organic molecule of nigher mass. Chlorine is certainly present in low concentrations, but was below the level of detection by our instrument. 
The temperature characteristics of this refuse burning facility were found to be very different from those obsereved at the WPAFB Facility as shown in Figures 12, 13, 14. The frequency of the temperature drop is much higher at the N/L Facility, and is of the order of once every three to five days. Over a period of 166 days the temperature dropped below $315^{\circ} \mathrm{C}\left(600^{\circ} \mathrm{F}\right)$ on 37 occasions amounting to $16 \%$ down time of the total period as measured with Probe $I$, and dropped 31 times over a period of 180 days or $10 \%$ down time for Probe II. Generally the temperature was down for only a few hours, but it was recorded on two occasions to remain low for about a week. The N/L Probe III temperature data showed that it was down only $6 \%$ of the time with 19 temperature excursions over the 48 day period of exposure.

Examination of the metallographic specimens prepared from the coupons indicated that the corrosion found on N/L Probe I was more extensive than on the WPAFB probe. Furthermore, the encrustation on the N/L probes was thicker than that observed on the WPAFB probe and varied in thickness from approximately $0.04 \mathrm{~mm}(1 \mathrm{mil})$ to more than $10 \mathrm{~mm}(0.4$ inch). Figure 15 is a micrograph of a pit formed on SA178, and the electron probe X-ray analysis clearly shows the existance of a high content of chloride at the base of this pit as shown in Figure 16. Analysis of the base metal as seen in Figure 17, shows only iron and a trace of silicon. Similar photographs of SA213-T11 show the extensive pitting that occurred at the surface as seen in Figure 18 at $200 \mathrm{X}$ and Figure 19 at $1000 \mathrm{x}$. In this case the material above the pits was found to contain a varlety of elements, including chloride, as illustrated in Figure 20. Coupons taken from $\mathrm{N} / \mathrm{L}$ Probe II were found to be in very similar condition to those from $\mathrm{N} / \mathrm{L}$ Probe I. Examination of the N/L Probe II was made from the surface rather than through metallographic polishing of the cross sections. The spectrograph of a typical surface oxide of SA178 reveals nothing unusual as Figure 21 illustrates, but when the oxide is removed and the underside of the oxide is analysed, then we find an abundance of elements as shown in Figure 22. In this case sulphur is concentrated above all the other constituents. A top view of a pit after the oxide is removed from SA213-T11 is shown in Figure 23. N/L Probe III was exposed for only three months yet it underwent extensive attack. Figure 24 is a metallographic photograph of a pit with an agglomeration of material above it. The analysis of the material above the pit is shown in Figure 25, and a similar analysis at the base of the pit, showing the presence of chloride, is illustrated in Figure 26. The same trend was found throughout, and Figure 27 is the result of the analysis at the base of a pit in SA213-T22. A spectrograph of the epoxy mounting material is included to demonstrate the absence of any contaminating elements from this source, and is shown in Figure 28. With few exceptions, chloride was found to be concentrated at the base of pits in all five alloys exposed at the NASA Langley Refuse Burning Facility.

The pit depth data for N/L Probe II, exposed for six months, and N/L Probe III, exposed for three months, are shown respectively in Figures 29 and 30. Pit depths were not measured on N/L Probe I. Examination of these data indicates that the coupons exposed for three months experienced more severe pitting attack than the coupons exposed for six months. This is attributed to the period of the year that the probes were exposed. N/L Probe II was exposed through the winter months from September to April, 
and $N / L$ Probe III was exposed through the spring and summer months from April to July when grass clippings, loaded with moisture, become an additional burden to the incinerator. The manager of the NASA/Langley Faclilty estimated that during the summer months, grass clippings were 10 to $15 \%$ of the refuse. In fact, clippings were so plentiful on some occasions, especially after a weekend, that the operator had to feed the refuse carefuliy to avoid smothering the flames in the incinerator. Thus, the additional moisture in the combustion gases, during those months that the N/L Probe III was in place, increased the corrosion attack on the coupons.

In general, the data show that the 304 stainless steel underwent a fairly constant rate of attack over the exposure conditions of $\mathrm{N} / \mathrm{L}$ Probes II and III. With the exception of the 304 stainless steel, the other four alloys displayed an increased rate of pitting for both of the steels with a higher alloy content though the additional molybdenum in the SA213-T22 may have helped keep its pitting below that of the SA213-T11. The plain carbon steels, SA192 and SA178, tended to undergo less pitting than SA213-T22 or SA213-T11. The maximum rate of pit growth, calculated from these data, is listed for both probes in Table 3 , and shows that the rate of penetration in $\mathrm{N} / \mathrm{L}$ Probe II is considerably less than that for $\mathrm{N} / \mathrm{L}$ Probe III. It is important to note that the 304 stainless steel on Probe II displayed the highest maximum rate of pitting at $228 \mathrm{um} / \mathrm{yr}$ ( $9 \mathrm{mils} / \mathrm{yr}$ ) and SA 192 has undergone the lowest maximum pitting rate at $193 \mathrm{um} / \mathrm{yr}$ $(7.6 \mathrm{mils} / \mathrm{yr})$. For $\mathrm{N} / \mathrm{L}$ Probe III the rates of pit growth are higher, and in this case the SA213-T11 shows the highest maximum rate of pit penetration at $726 \mathrm{um} / \mathrm{yr}(28.6 \mathrm{mils} / \mathrm{yr})$ and 304 stainless steel the lowest rate at $366 \mathrm{um} / \mathrm{yr}(14.4 \mathrm{mils} / \mathrm{yr})$. An evalution of the effect of temperature shows that the data are not consistent for the two N/L probes, but the 304 stainless steel does tend to show an increase in pit depths at the higher temperature toward the tip end of the probes. This inconsistent effect of temperature may be a reflection of the temperature fluctuations of the incinerator for the following two reasons. First, this temperature change raises stresses within the oxide and the encrusted material leading to cracks in the encrustation which, in turn, exposes the underlaying metal to the corrosive atmosphere. Second, and perhaps more important, these temperature drops cause condensation of moisture and other condensable matter that can lead to corrosive attack of the coupons or boiler tubes. Such cracks are readily apparent in the photomicrographs of Figures $15,18,19$. Thus, these large temperature fluctuations can override any corrosion effects at the higher temperatures.

Summary and Discussion

It is clear, from examination of the data, that the environment at the N/L refuse burning facility is more corrosive than the environment at the coal fired boiler at WPAFB. The combustion gases formed from the burning of refuse are much more complex and contain more corrosive materials than the combustion gases generated by burning coal, and the spectrographic gas analysis support this. The high moisture content of the refuse, and, in particular the lawn clippings, increases the aggressiveness of the environment, and the large temperature fluctuations, as measured at the NASA/Langley Facility can only aggravate the already bad condition. The corrosion attack observed on the coupons from the WPAFB probe was of a more general type of attack, and the pits that formed tended to be shallow. Further- 
more, chloride was not found in any of the pits found on the WPAFB probe coupons. On the other hand, the coupons taken from the $\mathrm{N} / \mathrm{L}$ probes displayed a more localized pitting type of attack with deeper pits, and it was common to find chlorides at the base of the pits.

All the alloys performed better at the WPAFB Facility, but the 304 stainless steel was more resistant to attack than the other four steels. The low carbon steels, SA178 and SA192, performed slightly better in this coal fired environment than the higher alloy steels, SA213-T11 and SA213-T22, with the SA213-T22 undergoing the most severe attack. During the winter months at the NASA/Langley facility, the 304 stainless steel displayed the highest attack of the five steels, but during the spring and summer, it remained essentially unchanged in rate of attack while the other lower alloy steels exhibited a dramatic increase in pitting attack. The SA213-T11 and the SA213-T22 low alloy steels both underwent more attack than the two low carbon steels, SA192 and SA178. Thus, for year round performance the 304 stainless steel withstood the changing corrosive conditions best of the alloys studied.

Disclaimer

Certain commercial equipment, instruments, or materials are identified in this paper in order to adequately specify the experimental procedure. Such identification does not imply recommendation or endorsement by the National Bureau of Standards, nor does it imply that the materials or equipment identified are necessarily the best avallable for the purpose. 


\section{TABLE 1}

Alloy

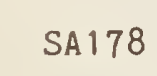

SA 192

SA213-T11

SA213-T22

304

\section{Composition \%}

$$
\begin{array}{lllllllll}
\mathrm{C} & \mathrm{Mn} & \mathrm{S} & \stackrel{\mathrm{P}}{\mathrm{S}} & \mathrm{Si} & \mathrm{Cr} & \mathrm{Ni} & \mathrm{Mo}
\end{array}
$$

$\begin{array}{lllllllll}.11 & .54 & .022 & .01 & .04 & - & - & - & -\end{array}$

$\begin{array}{llllllll}.12 & .45 & .013 & .014 & .82 & 1.14 & -- & .48\end{array}$

$\begin{array}{llllllll}.11 & .43 & .18 & .13 & .32 & 2.2 & - & \end{array}$

$\begin{array}{llllllll}.03 & 1.74 & .017 & .033 & .46 & 18 & 9.75 & -\end{array}$ 
TABLE 2

Maximum Rate of Pitting

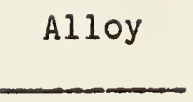

SA 178

SA 192

SA213-T11

SA213-T22

304
WPAFB Probe I - 6 months $\mathrm{um} / \mathrm{yr}$ (mils/yr)

$$
\begin{array}{ll}
150.6 & (5.9) \\
150.6 & (5.9) \\
159.7 & (6.3) \\
191 & (7.5) \\
98.6 & (3.9)
\end{array}
$$




\section{TABLE 3}

Maximum Rate of Pitting

$\begin{array}{ccc}\begin{array}{c}\text { Alloy } \\ \text { SA178 }\end{array} & \begin{array}{c}\text { Probe II }-6 \text { months } \\ \text { um/yr (mils/yr) }\end{array} & \begin{array}{c}\text { N/L Probe III }-3 \text { months } \\ \text { um/yr (mils/yr) }\end{array} \\ \text { SA192 } & 193(7.6) & 481(18.9) \\ \text { SA213-T11 } & 226(8.9) & 726(28.6) \\ \text { SA213-T22 } & 219(8.6) & 536(21.0) \\ 304 & 228(9.0) & 366(14.4)\end{array}$


Adams, A. B., Jr., Corrosion Problems with Wet Scrubbing Equipment, J. Air Pollution Control Assoc., 26 (4):303-307 (1976).

Anon, Reheat Study and the Corrosion-Erosion Tests at TVA's Colbet Pilot Plant, Electric Power Res. Inst. Rep. EPRI FP 940 (1979)

Anon, Refuse--A New Frontier for NASA in 200-tpd Steam-from-waste Plant, Solid Wastes Management Refuse Removal Journal 23(8), 46-50, 98-100, $103(1980)$

Anon, Principles of Industrial Water Treatment, Drew Chemical Corp., Boonton, NJ (1977)

Anon, Fluidized-bed Coal Technology Commercially Ready for Industrial Use; Environmentally Clean Way to Burn Coal, Resources-Recovery/Energy Rev. $\underline{5}(2), 20-21,1978$

Anon, Spray Dryers Absorb 502, Chemical Engr. 85(17), 55-56 (1978)

Anon, Boiler Treatment to Cut Pollution Being Market-tested in U.S., 0 il and Gas Journal 70(2): 58-59 (1972)

Anon, Packingless Plastic Pumps for Flow Rates to 5,000 gpm, Chemical Processing, Chicago 41(13), 76, 1978

Anon, Two Venturi/tray Scrubbers Clean Wastwater Gases, Chemical Processing, Chicago $42(7), 120$ (1979)

Anon, Small Incinerators Do the Job, American City and County 93(9), 97-98 (1978)

Backus, Eugene, Municipal Incinerator Defeats Pollution/Corrosion Problems, Civil Engr. 41 (12): 48-49 (1971)

Barniske, L., Energy from Waste Utilization in the Federal Republic of Germany, Solid Wastes 68 (2), 64-82 (1978)

Bartlett, H.D., Persson, S., Regan, R. W., et al., in American Society of Agricultural Engineers, Paper 77-4053, 1977, 9 pp.

Battelle Memorial Inst., Corrosion Studies in Municipal Incinerators, Government Reports Announcements, 73 (3): 115 (1973)

Bereiter, R., and Nuesch, P., Verhuetung von Verschmutzungen in Muellgefeuerten Kesseln, VGB Kraftwerkstech 59, 662-664 (1979)

Biondo, S. J., Flue Gas Desulfurization: Technical Issues and Problems, Proc. Fourth Symp. on Coal Utilization, 279-284 (1977)

Bratchikov, V. N., Influence of the Fractional Composition of Ash on the Erosion of Convective Boiler Heating Surfaces, Teploenergetika, pp. 91-92, (1971)(Eng. trans1. Thermal Eng. 18, 126-129 (1971) 
Buchowiecki, Ryszard, and Bukala, Cezary, Resistance of Plasma-deposited 0xide Coatings and Aluminum Coatings to Ash Erosion, Przeg1. Mech. 34, 529-531 (1975)

Cavazzana, Vittorio, and Della Rocca, Carlo, Methods of Corrosion Control and Inhibition in the Boiler Waters, Termotecnica (Milan), 32, 13-20 (1978)

Chamberlain, R. E., and Wostradowski, R. A:, Key to Recovery Boiler Performance is an Understanding of Variables, Pulp \& Paper 52(3), 96-101, (1978)

Colby, G. R., High Temperature Corrosion in Incinerator Heat Recovery Units, National Association of Corrosion Engineers:Corrosion/74, Paper 132 (1974)

Crawford, A. R., Manny, E. H., and Bartok, W., Field Testing: Application of Combustion Modification to Power Generating Combustion Sources, Proc., Second Stationary Source Combustion Symposium, New Orleans, LA, Aug. 29-Sept. 1, 1977

Crits, G. J., Quality of Makeup Water Needed for Steam Generating Systems, Indus. Water Engr. 12 (1), 5-7, (1975)

Curtiss-Wright Corp., Engineer, design, Construct, Test, and Evaluate a Pressurized Fluidized Bed Pilot Plant Using High Sulfur Coal for Production of Electric Power. Phase i. Prel iminary Engineering Technology Support Test Results, Commercial Fluid-Bed Long Term Errosion/Corrosion Test in a Municipal Sewage Incinerator, CurtissWright Corp., Wood-Ridge, NJ (Department of Energy 9502799)

Defeche, J., Corrosions Produced by the Incineration of Domestic Refuse, Electricite de France, Paris, Citation No. 71-1TF-0158, 488-508 (1969)

Dicks, J. B., Tempelmeyer, K. E., Wu, Y. C. L., and Crawford, L., Investigation of Direct Coal-fired MHD Power Generation, Proc. 11 th Intersoc. Energy Convers. Eng. Conf., State Line, NV, 1976, SAE Paper 769177, p. 1015-1019.

Donahue, Bernard, 0xley, J., and Buie, C., Analys is of Flue Gas Desulfurization (FGD) Processes for Potential Use on Army Coal-fired Boilers, Construction Engineering Research Lab. (Army) Rept. No. CERL-TR-N-93, (1980)

Dowdy, T. E., Lapple, W. C., Kitto, J. B., Stanoch, T. P., and Boll, R. H., Summary Evaluation of Atmosphere Pressure Fluidized Bed Combustion Applied to Electric Utility Large Steam Generators, Executive Sumary, Babcock \& Wilcox Co., Alliance, OH, (0704000), 1976

Effertz, P. H., and Resch, G., Combined Conditioning of Water-steam Cycle of Power Generating Units with Once-through Boilers by Oxygen and Ammonia, Proc. 39th Int. Water Conf. Annual Meeting, 1978, pp. 171-183.

Effertz, P. H., Fichte, W., Szenker, B., Resch, G., Burgmann, F., Gruenschlaeger, E., and Beetz, E., Combined Oxygen/Ammonia Conditioning of Water-steam circuits in Thermal Power Plants with Continuous-type Boilers, Maschinenschaden 51 (3), 97-109 (1978) 
Faige, N. G., Corrosion Service Experience and Economics of Titanium's Usage in Gas Scrubbing Equipment for Refuse Incinerators, National Association of Corrosion Engineers:Corrosion/74, Paper 138 (1974)

Foster-Pegg, R. W., A Coal-fired Fluid Bed Gas Turbine Cogeneration System, Combustion 50 (12), 29-35 (1979)

Franconeri, P., Electrostatic Precipitator Corrosion on Incinerator Applications, Abstracts 68th Annual Meeting, Air Pollution Control Assoc., p. 325 (1975)

Gambill, W. R., and Reed, W. R., Survey of Industrial Coal Conversion Equipment Capabilities: Heat Recovery and Utilization, Oak Ridge National Lab., TN, Department of Energy (4832000), 137 p., 1978

Gilbert, L. F., Sr., CD Control Heightens Furnace Efficiency, Chemical Engr. 87 (15), 69-73 (1980)

Gunn, D. C., Waste Heat Recovery in Boilers, Energy World 24, 2-6 (1976)

Jullien, J., Renovation of the smoke-stack of the urban waste incinerator of Ivry-on-the-Seine, Techniques et Sciences Muncipales et Revue l'Eau 75 (2), 77-83 (1980)

Knoll, H., Real Systems of Incineration, 15th international Symp. on Combustion, Pittsburgh, PA, The Combustion Institute (1974), pp. 222-223.

Krause, H. H., Corrosion and Deposits from Combustion of Solid Waste, IV: Combined Firing of Refuse and Coal, J. Engr. for Power 98 (3a), 369-374 (1976)

Krause, Horatio H., Factors Influencing the Corrosion of Boiler Steels in Municipal Incinerators, Corrosion 27 (1), 31-45 (1971)

Krause, H. H., Vaughan, D. A., Sexton, R. W., and Boyd, W. K., ErosionCorrosion Effects on Boiler Tube Metals in a Multisolids Fluidized-bed Coal Combustor, ASME Paper No. 77-WA/CD-1, for meeting November 27December 2, 1977

Krause, H. H., Vaughan, D. A., Sexton, R. W., and Boyd, W. K., ErosionCorrosion Effects on Boiler Tube Metals in a Multisolids Fluidized-bed Coal Combustor, J. Eng. Power Trans. ASME 101, 1-8 (1979)

Lange, K. R., Water Treatment Chemical Application to Gas Scrubber Systems, in Air Pollution Control and Industrial Energy Production, K. E. Noll, W. T. Davis, and J. R. Duncan, eds., Ann Arbor Science Publ. 1975, pp. 195-209

Luescher, K. H., Measures for Corrosion Protection of Tubes in Boilers Operating on Refuse-Incinerator Waste Heat, VGB Kraftswerkstechnik 53 , 87-93 (1973) 


\section{Thank you.}

Briget Wynne

NIST Research Library

> >X-Sieve: CMU Sieve 2.2

$>>$ Subject: Obtaining a copy of a report

> >Date: Mon, 6 Dec 2004 12:01:37 -0500

$>>$ X-MS-Has-Attach:

$>>$ X-MS-TNEF-Correlator:

$>>$ Thread-Topic: Obtaining a copy of a report

> >Thread-Index: AcTbtT+B591cFGwIQ4+PI6VSIWwtiQ==

>>From: "Richey, Billi J." <BJRichey@ southernco.com>

$>>$ To: <julian.ives@nist.gov>

>>X-OriginalArrivalTime: 06 Dec 2004 17:01:38.0257 (UTC)

$>$ FILETIME $=[4000 B C 10: 01$ C4DBB5]

$>>$ X-MailScanner:

> >X-MailScanner-From: bjrichey@southernco.com

$>$

$>>1$ work for Georgia Power and am doing some research on corrosion of

> >stainless steels. I was wondering how I go about getting a copy of a

> >report that was printed in 1984. I have the title and author and

report

> >\#, I just don't know how to go about getting a copy of the report.

$>>$

$>>$ Sincerely,

$>>$ BJ Richey

Briget Wynne

NIST Research Library

Interlibrary Loan \& Document Delivery

phone: $301-975-3981$

fax: $\quad 301-869-6787$

Briget Wynne

NIST Research Library

Interlibrary Loan \& Document Delivery

phone: 301-975-3981

fax: $\quad 301-869-6787$ 

Malaiyandi, M., Thomas, G. H., and Meek, M. E., Sampling and Analys is of Some Corrosion Inhibiting Amines in Steam Condensates, J. Environ. Sci. and Health, Part A: Environ. Sci. and Engr. Al4 (7), 609-627 (1979)

Mansfield, G. H., Water Quality and the Chemical Industry, Effluent and Water Treatment Journal 18 (6), 277-283 (1978)

Mason, G. J., and Colby, T., Incineration Ash Solves Solids Buildup at Vancouver, Water and Sweage Works 126 (10), 60 (1979)

Metcalf, J. H., Inhibition and Corrosion Control Practices for Boiler Waters, Corrosion Inhibitors, p. 196-219, Publ by NACE, Houston, TX (1973)

Michels, H. T., and Hoxie, E. C., How to Rate Alloys for $\mathrm{SO}_{2}$ Scrubbers, Chem. Engr. 85 (13), 161-166 (1978)

Miller, Paul D., Corrosion of Carbon and Stainless Steels in Flue Gases from Municipal Incinerators, Battelle Memorial Inst., Columbus, $\mathrm{OH}$, Citation No. 73-3TF-00343, pp. 300-309 (1972)

Millette, J. R., Clark, P. J., Pansing, M. F., and Twyman, J. D., Concentration and Size of Asbestos in Water Supplies, Environ. Health Perspectives $34,13-25$ (1980)

Mitre Corp., Proceedings of the Workshop on Utility/Industrial Implementation of Fluidized-bed Combustion Systems, Atlanta, Georgia, April 27-28, 1976 ,

Morresi, A. C., an'd Cheremisinoff, P. N., Cooling Water and Boiler Possibilities for Wastewater Reuse, Industrial Wastes 24 (2), 33-34 (1978)

Murphy, James D., Materials to Resist the Abrasion of Pneumatically Transported Processed Refuse, Proc. of 8th National Waste Process Conf.: Energy Conservation Through Waste Uti1., Chicago, IL, May 7-10, 1978, Publ by ASME, New York, NY, pp. 327-340

Niessen, W. R., Source, Supply, and Nature of Municipal and Industrial Waste as a Fuel, Energy Technology VI: Achievements in Perspective, R. F. Hill, ed., pp. 1015-1025, 1979

Depik, I., and 0ts, A., Ash Deposits, High Temperature Corrosion, and Heating Surface Erosion on Steam Generators with Combustible Shale Firing, VGB Kraftwerkstech 59, 977-983, 1979

Ondov, J. M., Ragaini, R. C., and Biermann, A. H., Evaluation of Two Particulate Collection Alternatives for Trace Element Removal at Coal-fired Power Plants, Abstracts of Papers, 71 st Annual Meeting Air Pollution Control Association, Pittsburg, PA, 1978

Ots, A. A., Anson, P. I., and Tallermo, Kh. I, Cleaning of Boiler Heating Surfaces with Water, Teploenergetika, 8, 49-54, 1979

Patrick, P. K., Operational Experience with Energy Recovery from Incineration of Solid Wastes, Ingegneria Ambientale Inquinamento e Depurazione No. 5, 554-560 (1978) 
Peacock, B., Renovation of Middle-aged Power Stations, Combustion 45, 45-48 (1973)

Pekker, Ya. L., and Lipov, Yu. M., Mechanism of Corrosion Failure of Firebox Waterwalls in Boilers Fired by Solid Fuel, Teploenergetike 10, 25-28 (1974)

Peters, A., Chemical Behavior of Inspection Glasses, in Particular BoronSilicate Glass, Exposed to Boiler Water at Elevated Temperatures, VGB Kraftswerkstech $\underline{55}, 128-132$ (1975)

Radway, J. E., How More Ash Makes Less, Environ. Sci. and Tech. 12 (4), $388-391,1978$

Reed, R. D., Nitrogen 0xides Problems in Industry, Chem. Engr. 84 (22), 153-157 (1977)

Reidick, H., and Reifenhaeuser, R., Catalytic $\mathrm{SO}_{3}$ Formation as Function of Boiler Fouling, Combustion 51 (8), 17-21 (1980)

Rich, G. A., and Cherry, K. F., Problems in Upgrading Multiple Cyclones, Pollution Engr. 11 (5), 59-60 (1979)

Sauer, R. E., Electrostatic Precipitator Cuts Back Refuse Incinerator's Air Pollution; Nashville's Thermal Plant Now Betters EPA Standards, Solid Wastes Management Refuse Removal Journal 22 (5), 51-56 (1979)

Schieber, J. R., Cooling Tower Blowdown and Boiler Blowdown as Waste Water Problems, Betz Labs., Inc., Universal Interloc, Inc., Trevose, PA, See Citation No. 71-4TF-704, pp. 18-23, 1971

Schutz, Herbert, Gasanalytische Ueberwachung von Muellverbrennungsanlagen, Wasser, Luft und Betrieb. 14 (4), 152-156 (1970)

Scott, W. S., and Wylie, N. P., The Environmental Effects of Snow Dumping: A Literature Review, J. Environ. Management 10 (3), 219-240 (1980)

Serper, A., Anticipation of Environmental Impacts of Facilities Urged, Solid Wastes Management Refuse Removal Journal 21 (3), 60,62,64,88 (1978)

Stabenow, Georg, Design Criteria to Achieve Industrial Power Plant Reliability In Solid Waste Processing Plants with Energy Recovery, Proc. 8th Natl. Waste Process Conf.: Energy Conservaton Through Waste Util, Chicago, IL, May 7-10, 1978, Publ. by ASME, New York, NY, 1978, pp. 427-446.

Sundarrajan, M., Erosion Problems in Coal-fired Utility Boilers and Their Auxiliaries, Indian J. Power River Val. Dev. 24, 323-331 (1974)

Suurkuusk, T. N., Heat Reception and Corrosion/Erosion Wear of Screen Steam Superheaters Due to Steam Blowing, Teploenergetika, 2, 19-23 (1975) 
Swinehart, G. A., and Sanders, W. A., II, Waste-to-energy: Applying the Technology in the Real World, Solid Wastes Management Refuse Removal Journal 22 (5), 20-28, 88 (1979)

Tatone, 0. S., and Pathania, R. S., Steam-generator Tube Performance: World Experience with Water-colled Nuclear Power Reactors During 1978, J. Environ. Economics and Management 7 (3), 766-780 (1980)

Tieman, John W., Control of Sulfur Dioxide Emissions, Int. Workshop on Environ. Problems of the Extr. Ind. Pap. Dayton, Ohio, June 10-13, 1973, Paper 12, pp. 145-168, Publ. by Ann Arbor Sci. Publ. 1974

Thoeman, Karl-Heinz, Contribution to the Control of Corrosion Problems on Incinerators with Water-wall Steam Generators, Stadtwerke Duesseldorf, FGR, Citation No. 73-3TF_00343, pp. 310-318 (1972)

Thurnau, R. C., Incineration of Liquid and Solid Waste, Paper presented at Midwinter Conference on Textile Wastewater Treatment and Air Pollution Control, (1973)

Vaughan, D. A., Corrosion and Deposits from Combustion of Solid Waste: Part III: Effects of Sulfur on Boiler Tube Metals, J. Engr. for Power g7 (3), 448-452 (1975)

Veater, F. M., Corrosion Resistant Refractory Linings and Mortars for Incinerators and Chimneys, National Association of Corrosion Engineers: Corrosion/74, in Natinoal Assoc. of Corrosion Engineers, Paper 134, (1974)

Velzy, C. 0., Corrosion Experiences in Incineration, National Association of Corrosion Engineers:Corrosion/74, in National Assoc. of Corrosion Engineers, Paper 133 (1974)

Vesilind, P. A., and Warner, D., Combustion, Bioconversion, Source Separation, and Disposal of Residuals, sol id Wastes Management Refuse Removal Journal 21 (6), 68-74 (1978)

Vlahakis, J., Jacobsen, W., and Miller, G., Materials Separation Processes, Electrotechnology, Vol. 1, Wastewater Treatment and Separation Methods, R. P. Ouellette, J. A. King, and P. N. Cheremisinoff, eds., Ann Arbor Science Publ, 1978, pp. 1-14

Vlahakis, J., Jacobsen, W., and Miller, G., Reverse Osmosis, Electrotechnology Vol. 1: Wastewater Treatment and Separation Methods, R. P. Ouellette, J. A. King, and P. N. Cheremisinoff, eds., Ann Arbor Science Publ, 1978, pp. $41-73$

Voegtle, J. A., Foster, W. E., and Martin, D. W., Startup of a Municipal/ Industrial Solids Processing Facility, Water Pollution Control Federation Journal 51 (5), 926-937 (1979) 
Weidman, G. H., Liquid Fuel Analyses--Their Effect on Combustion and Emissions, Babcock \& Wilcox, Industrial \& Marine Div., Power Generation Group, N. Canton, OH 44720 (1976)

Wiggin, F. T. F., Experience at Edmonton (GLC) of Generating Electricity Using Refuse as Fuel, Proc. Inst. Electr. Eng. (London), 125, 169-172 (1978)

Yocum, J. E., Air Pollution Damage to Buildings on the Acropolis, Air Pollution Control Assoc. Journal 29 (4), 333-338 (1979)

Zanitsch, R. H., and Lynch, R. T., Selecting a Thermal Regeneration System for Activated Carbon, Chem. Engr. 85 (1), 95-100 (1978) 


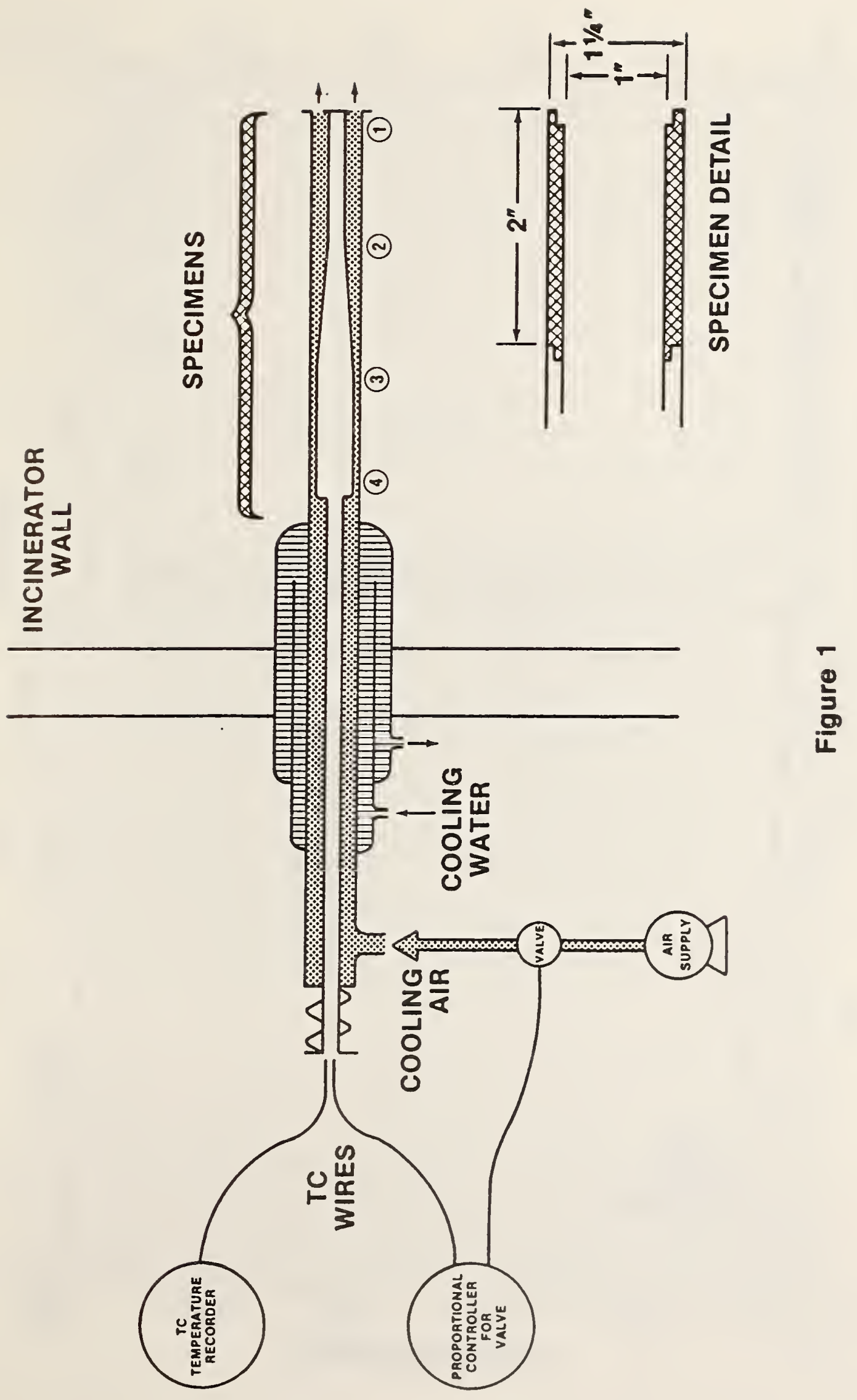




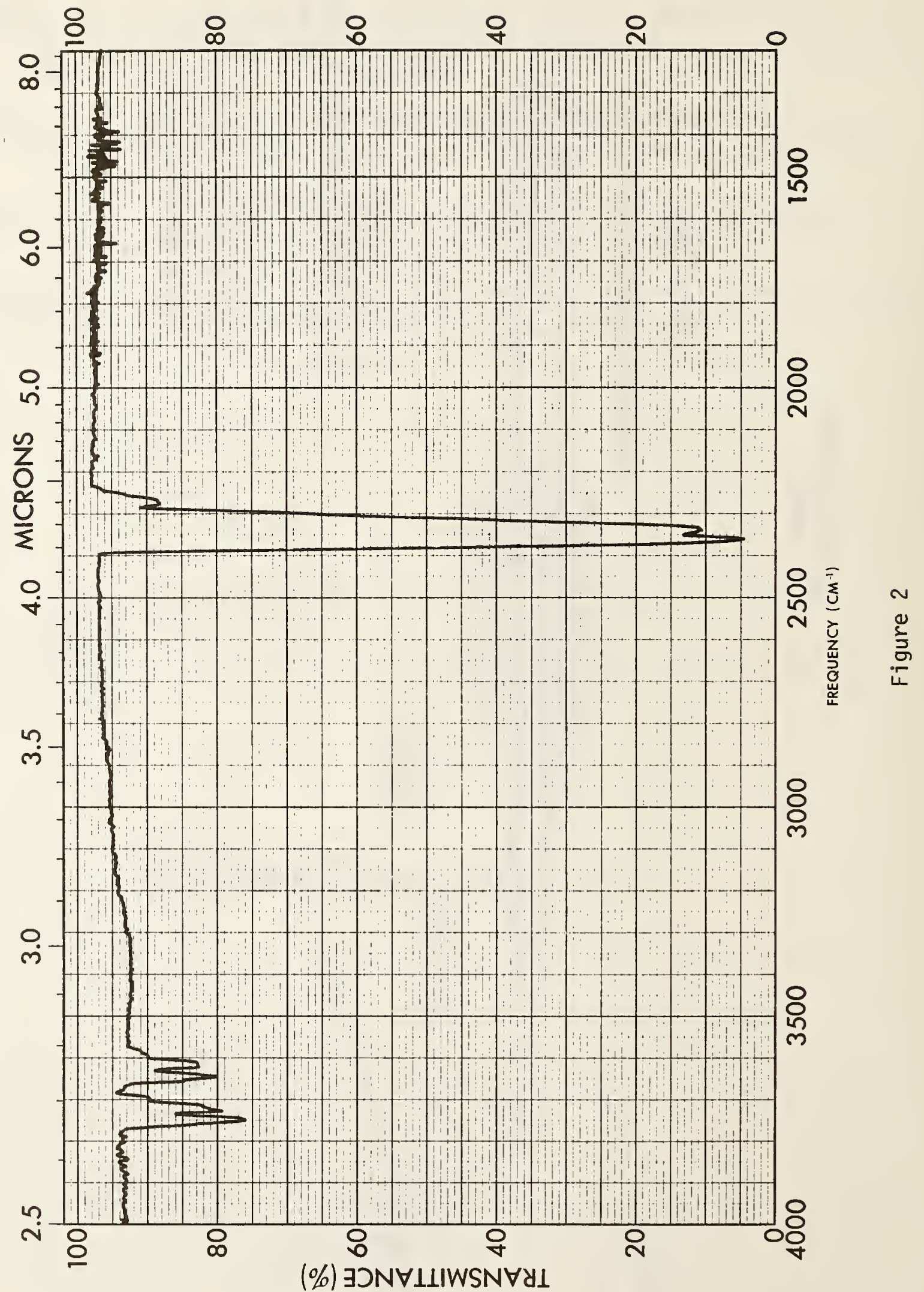




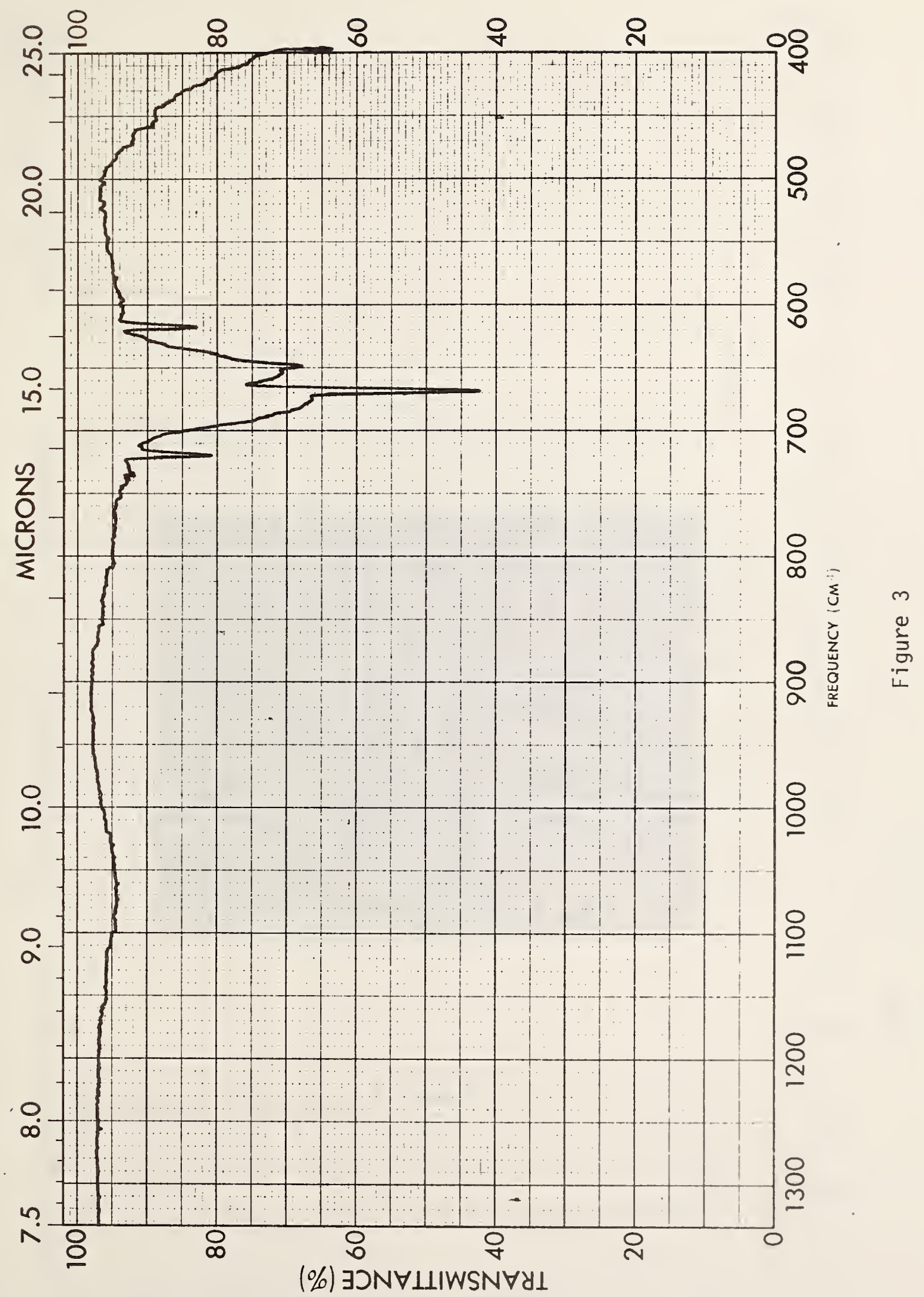




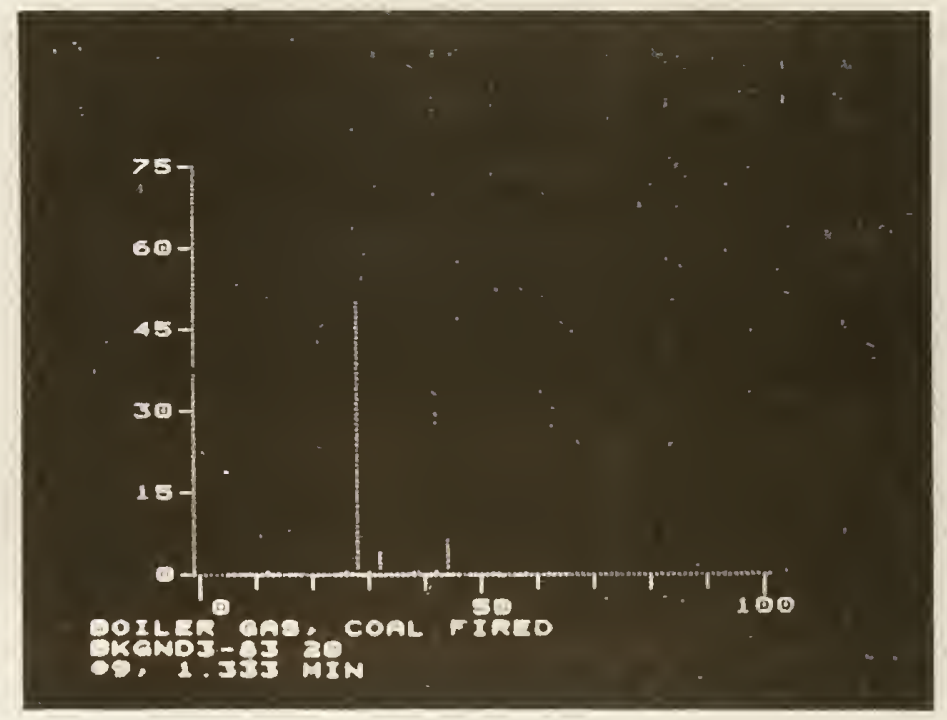

Figure 4 


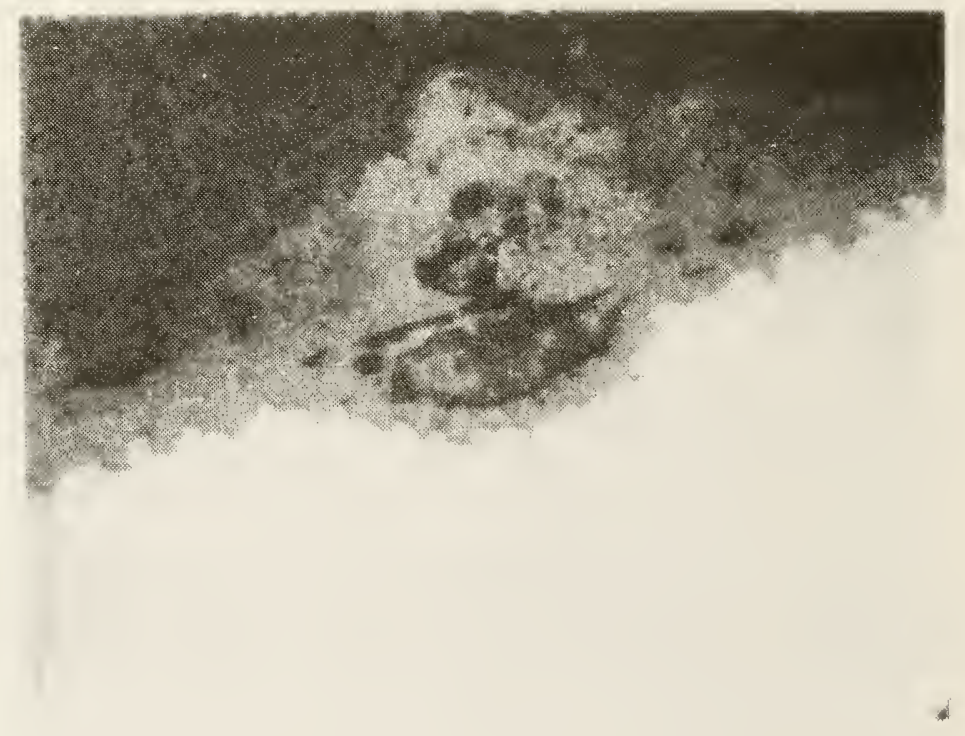

Figure 6 


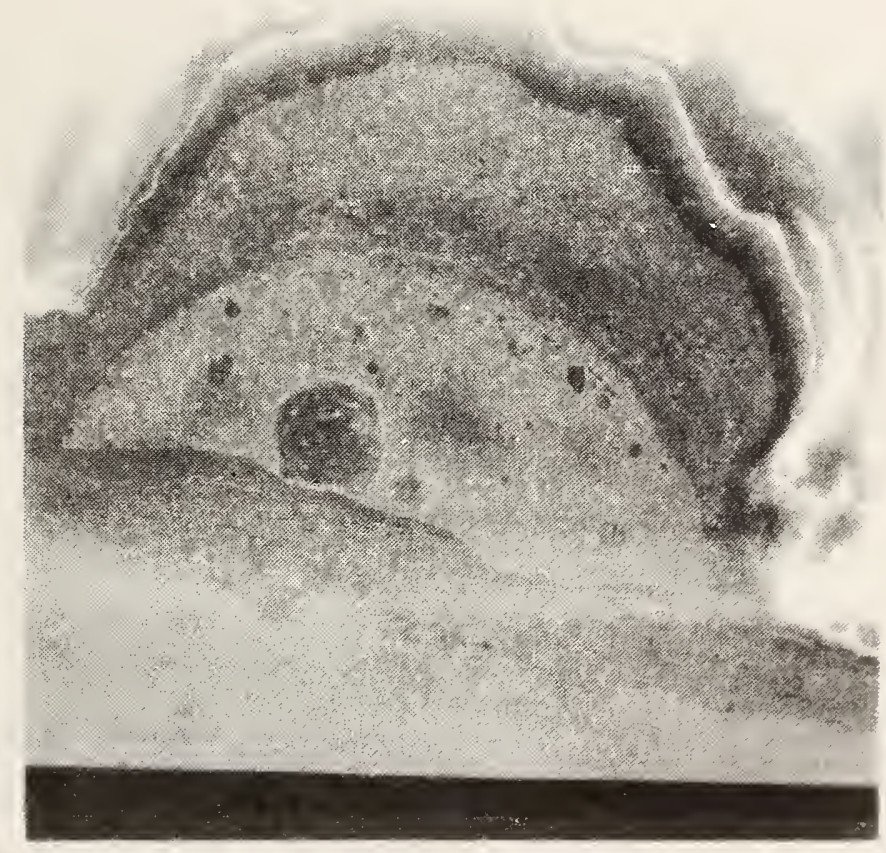

Figure 7 


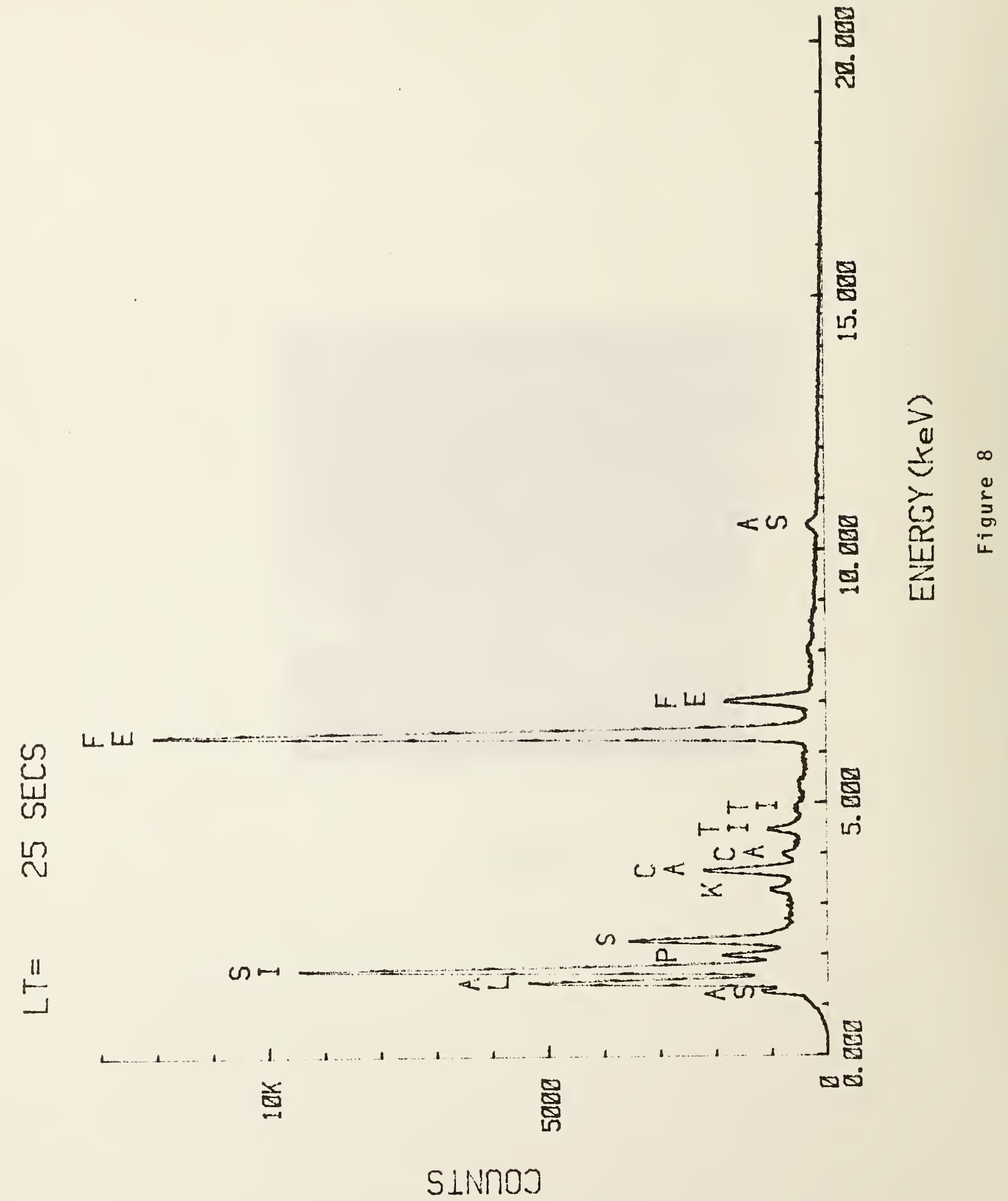


s!!u 'yłdəg I!d unu!xew

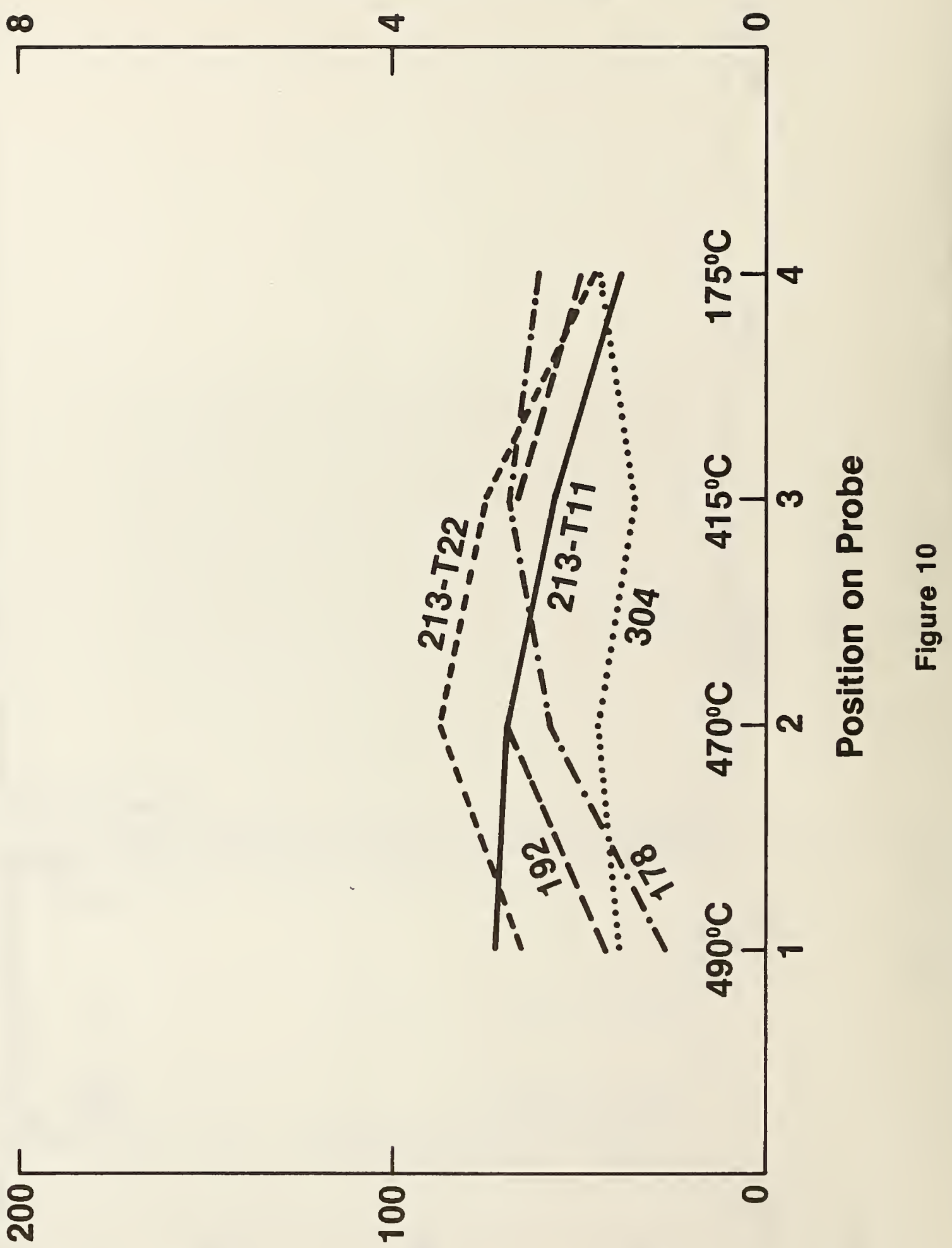

\section{wrl 'yldea H!d unu!̣xew}




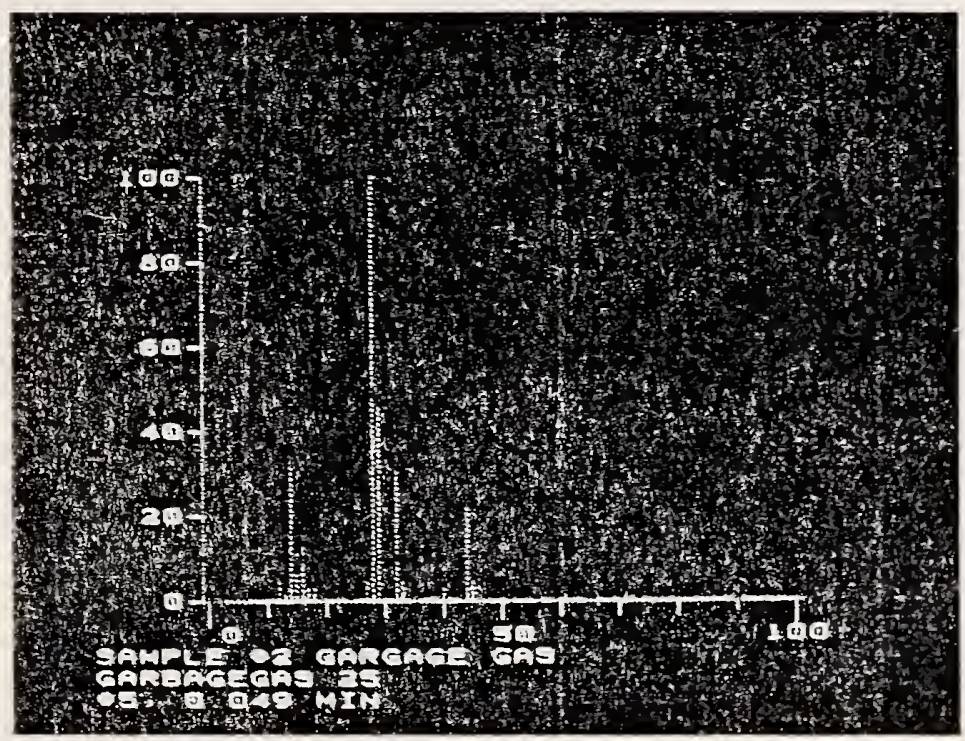

Fiqure 11 


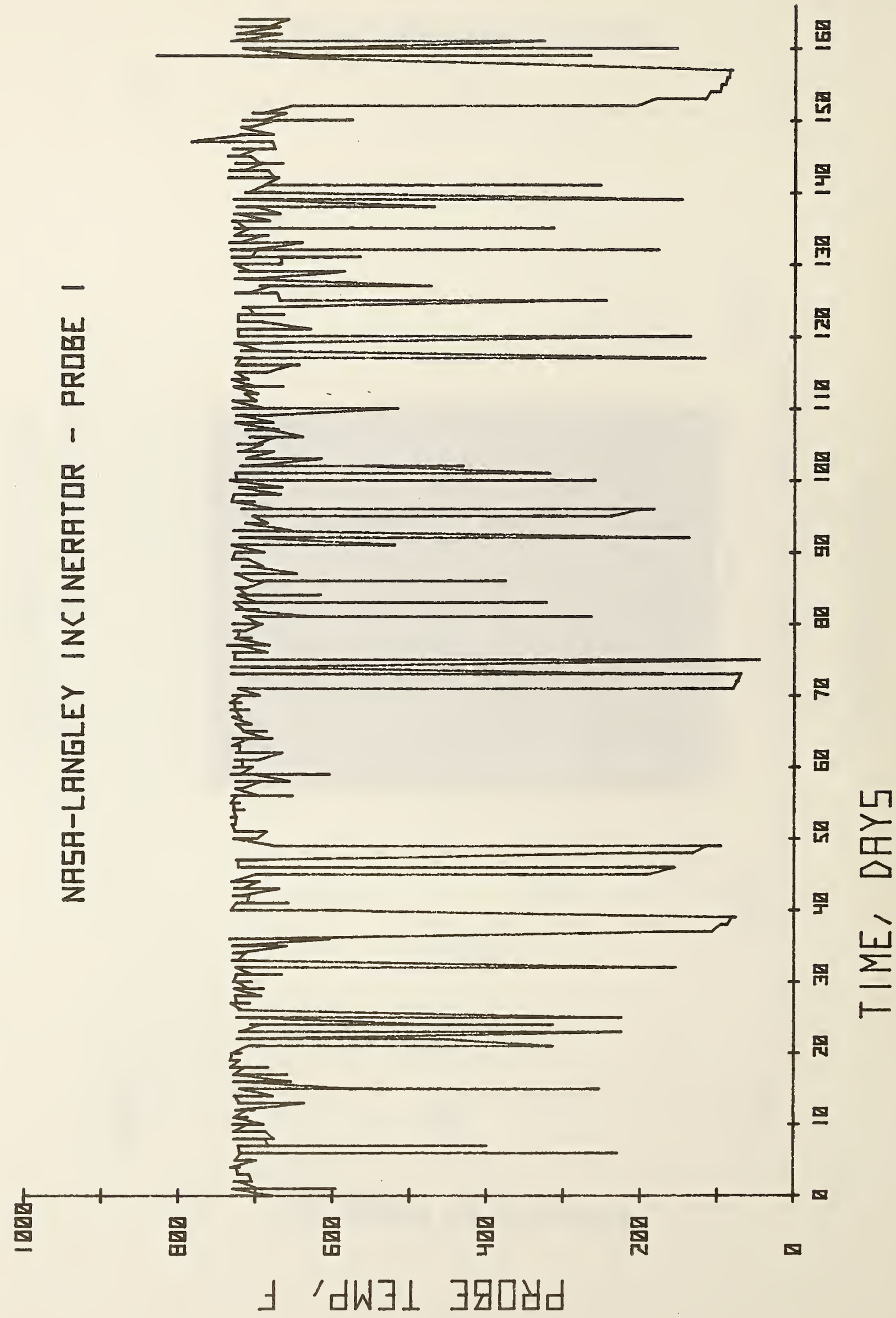




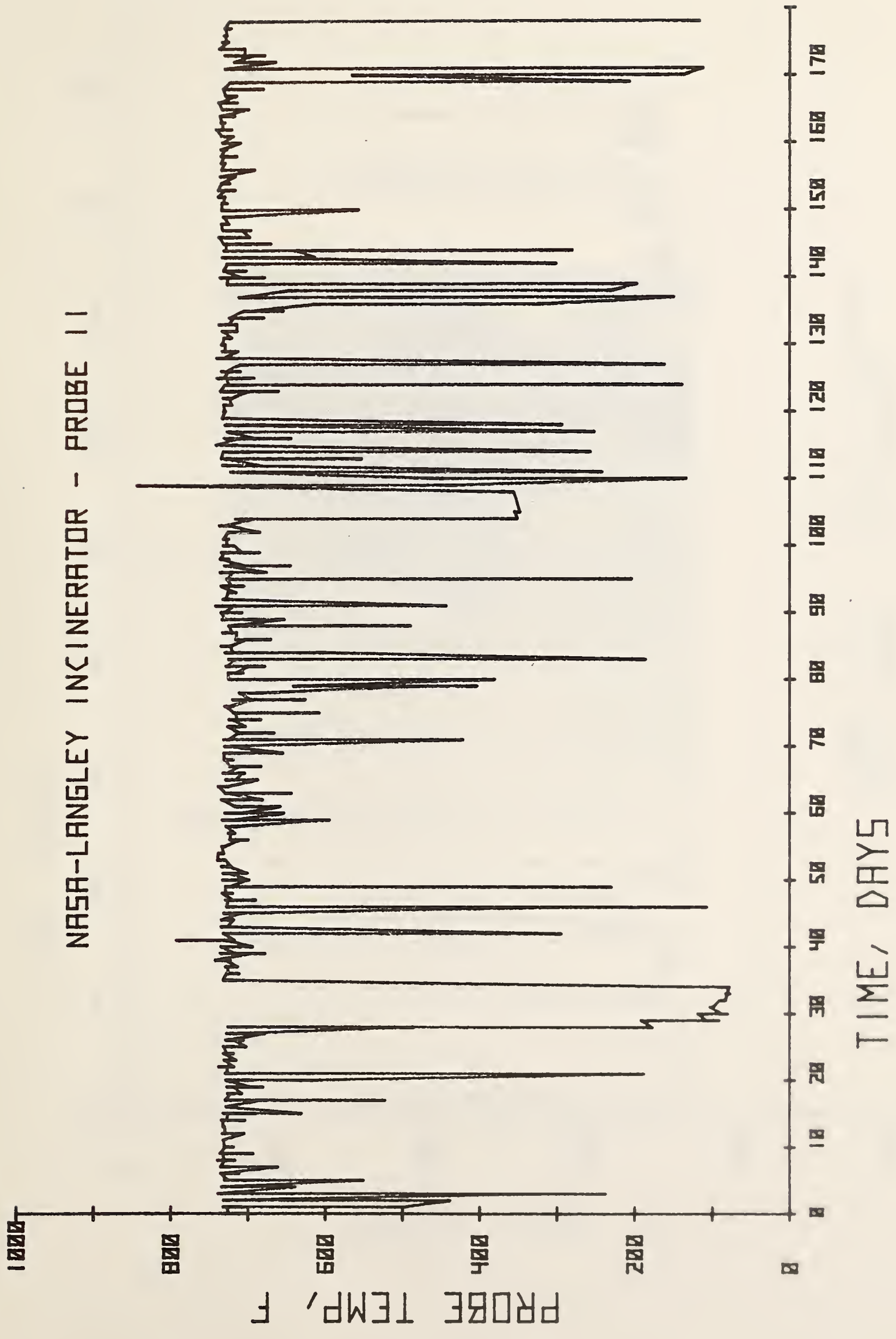




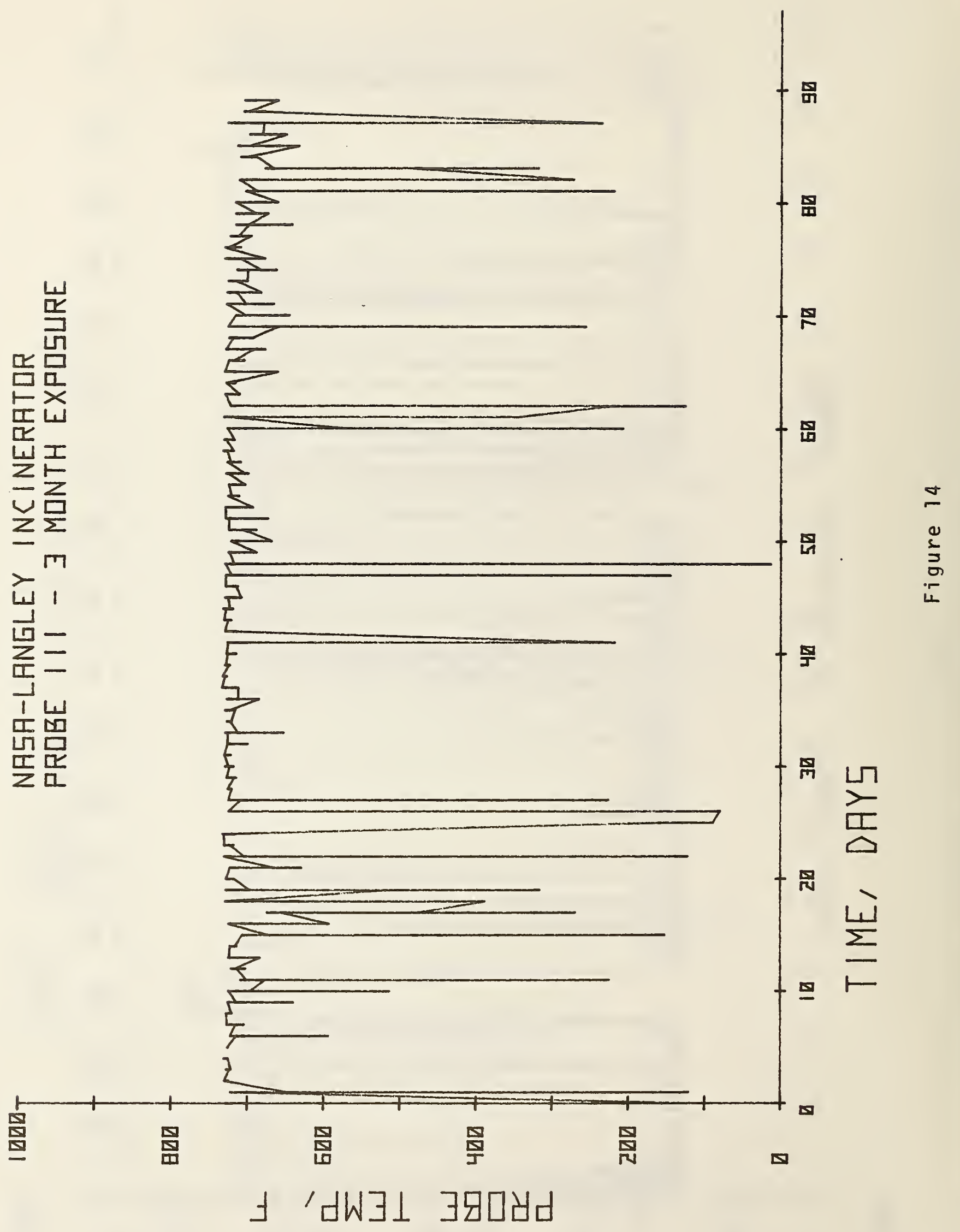




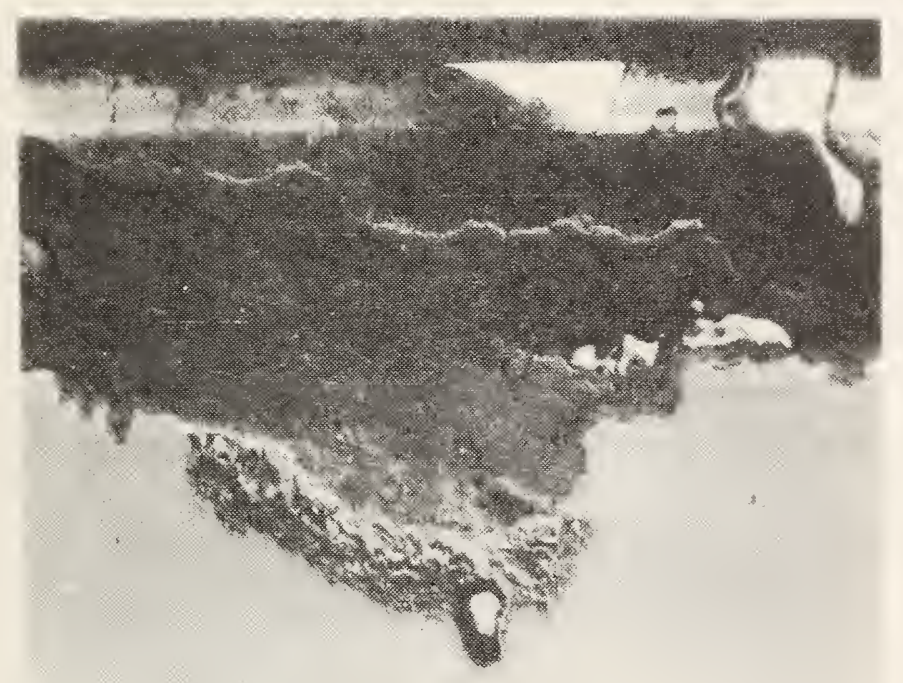

Fiqure 15 


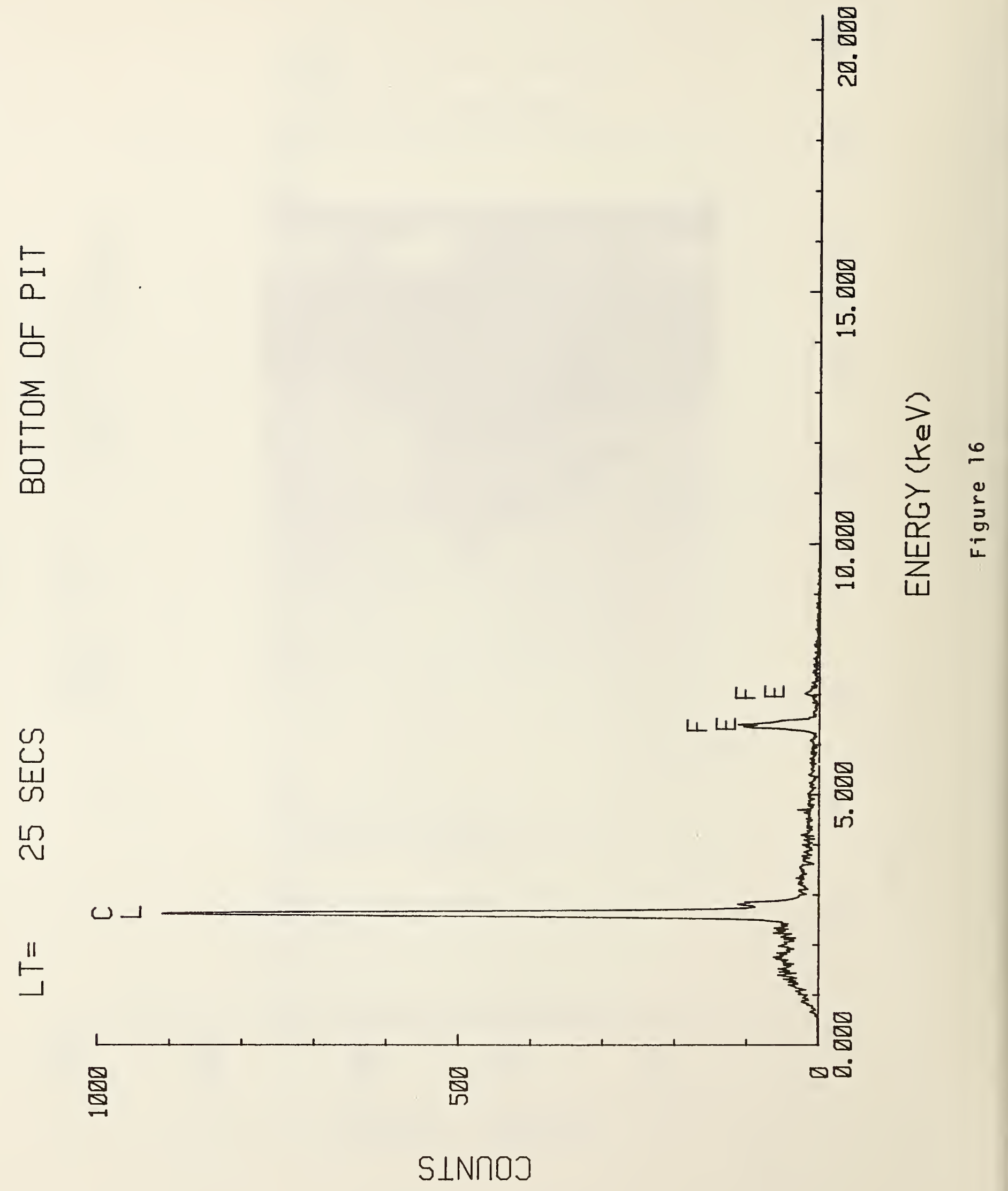




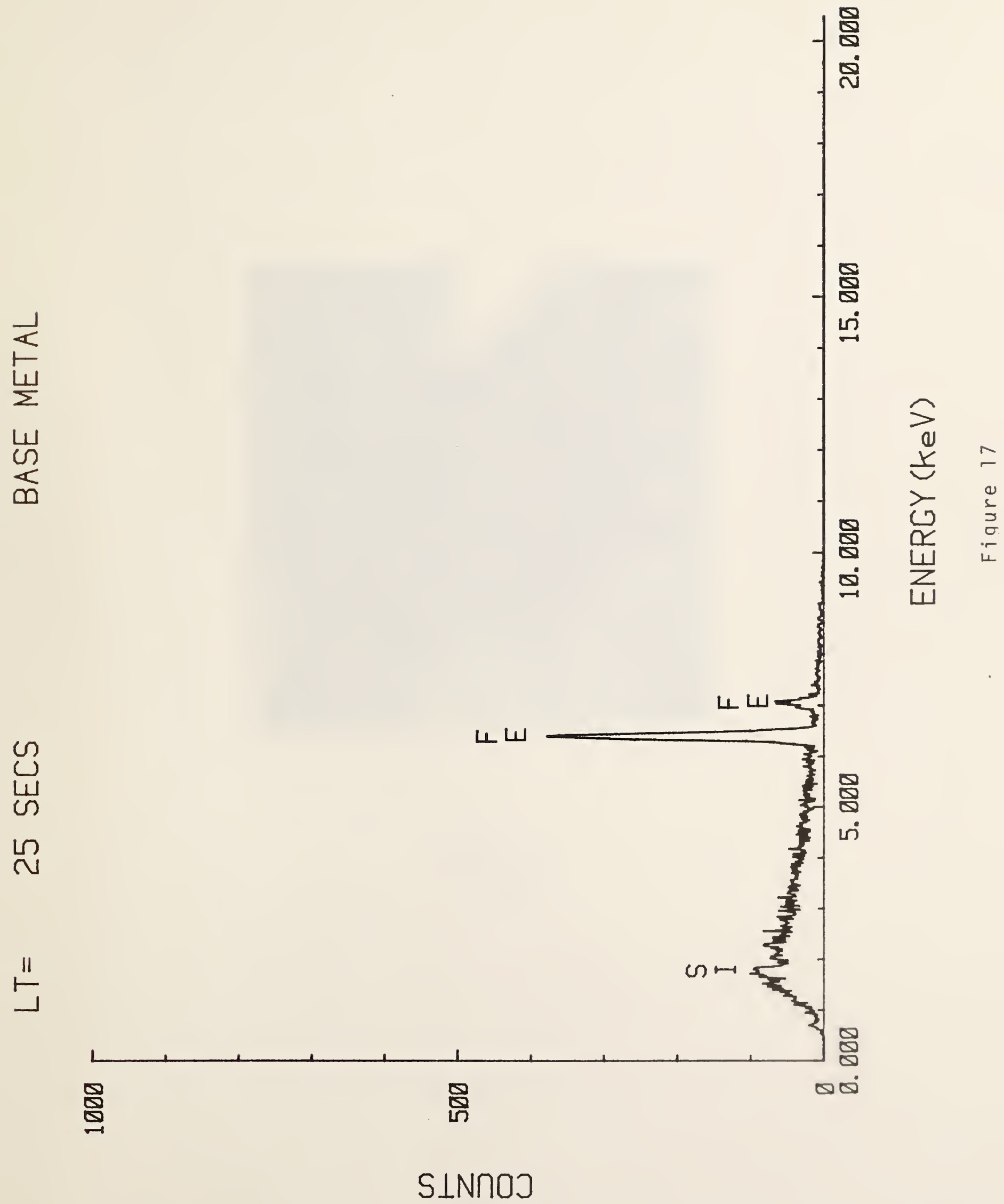




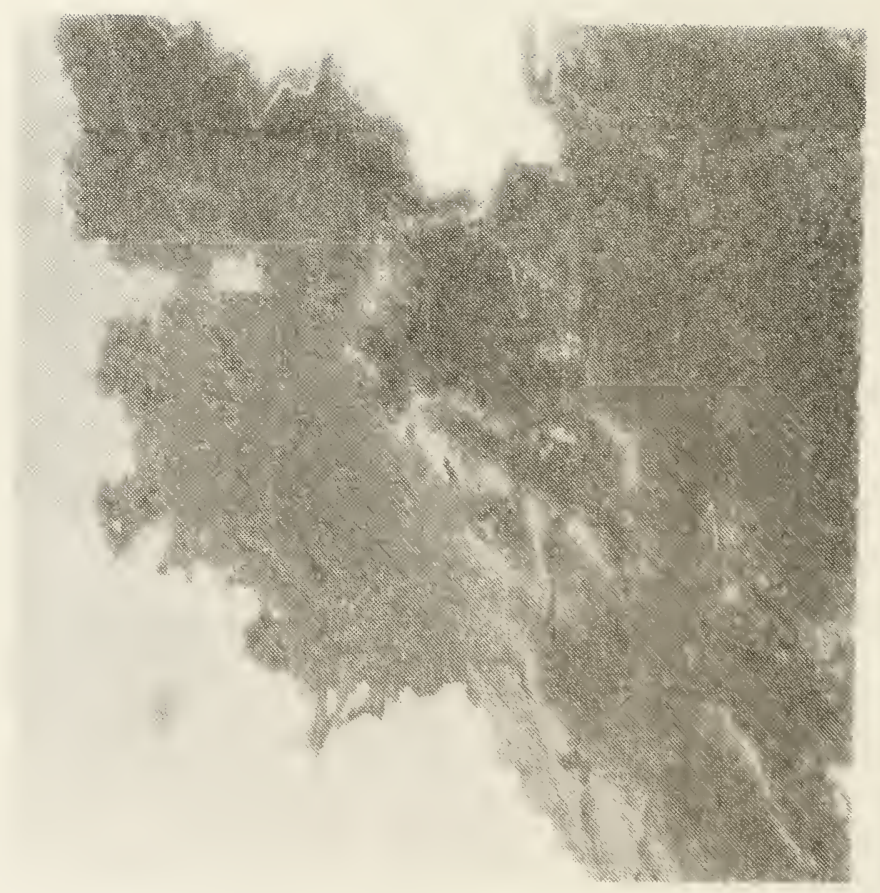

Figure 18 


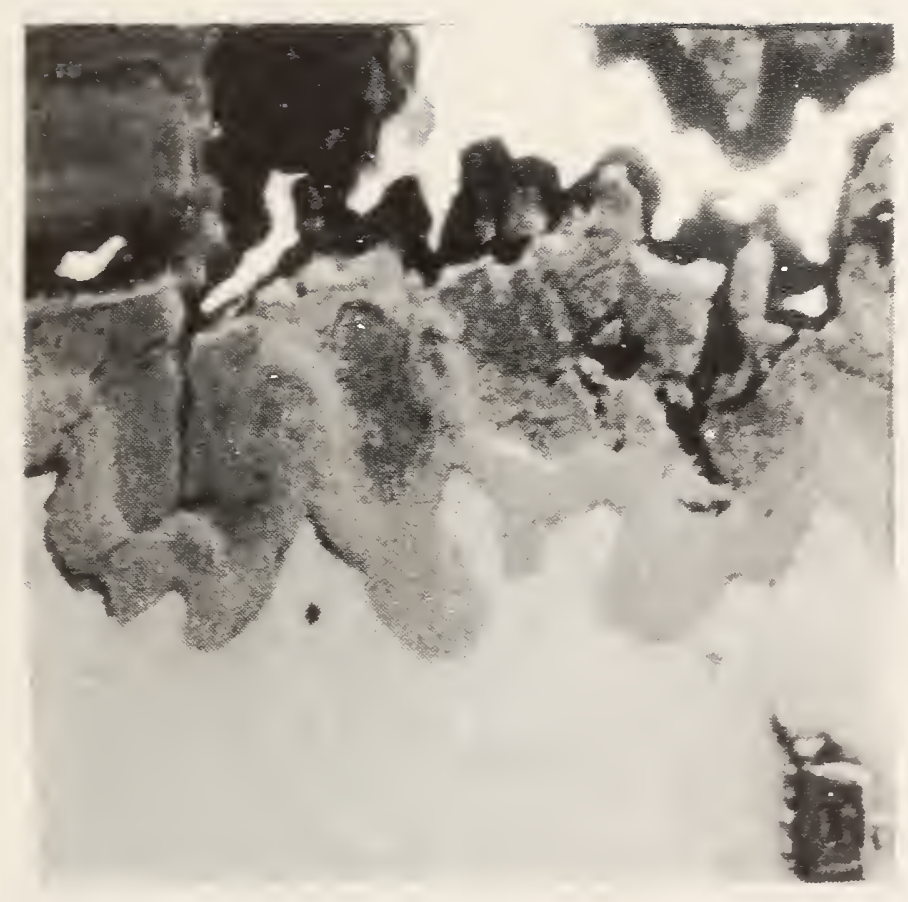

Figure 19 


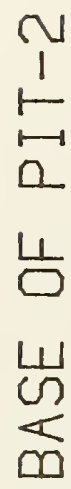

U

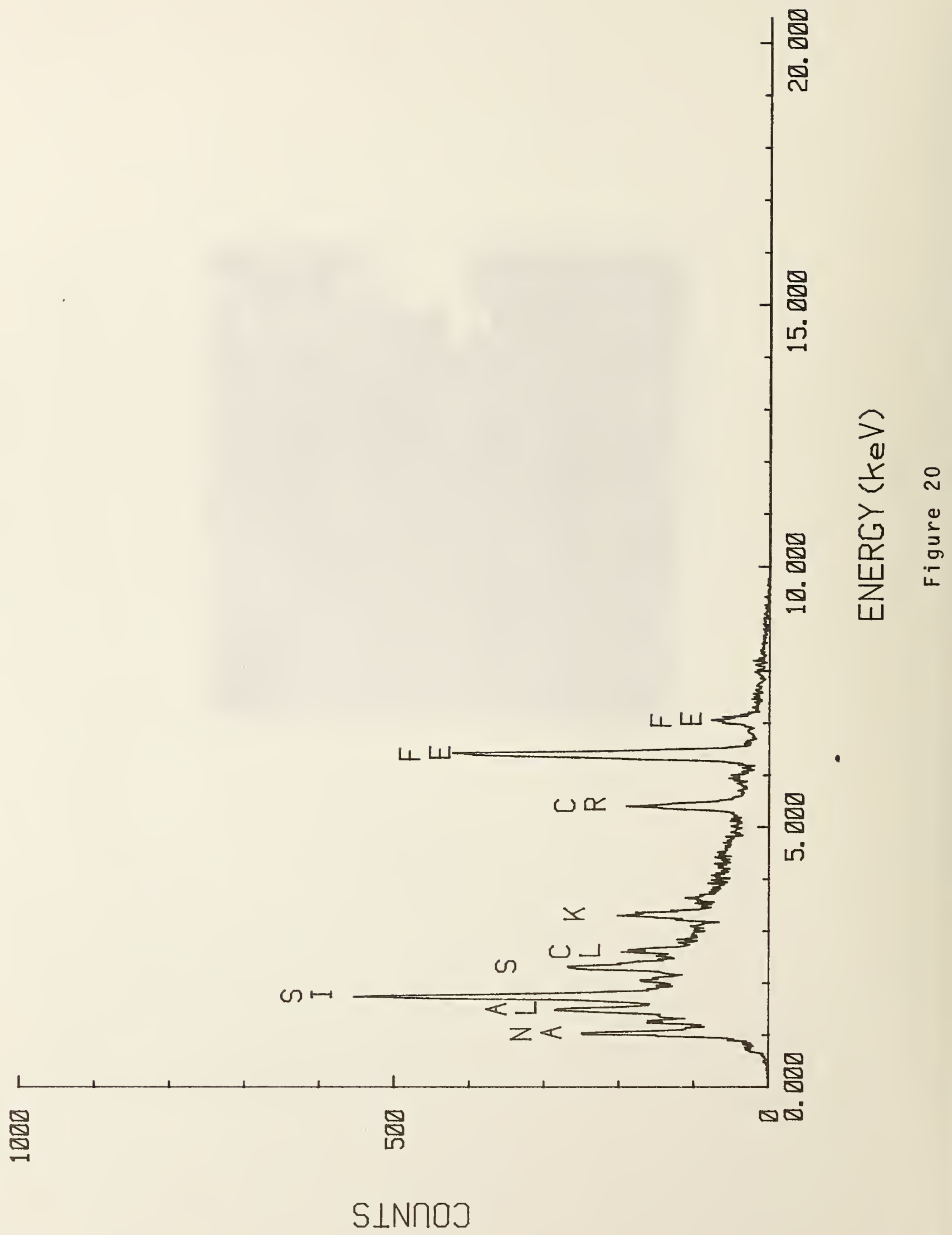




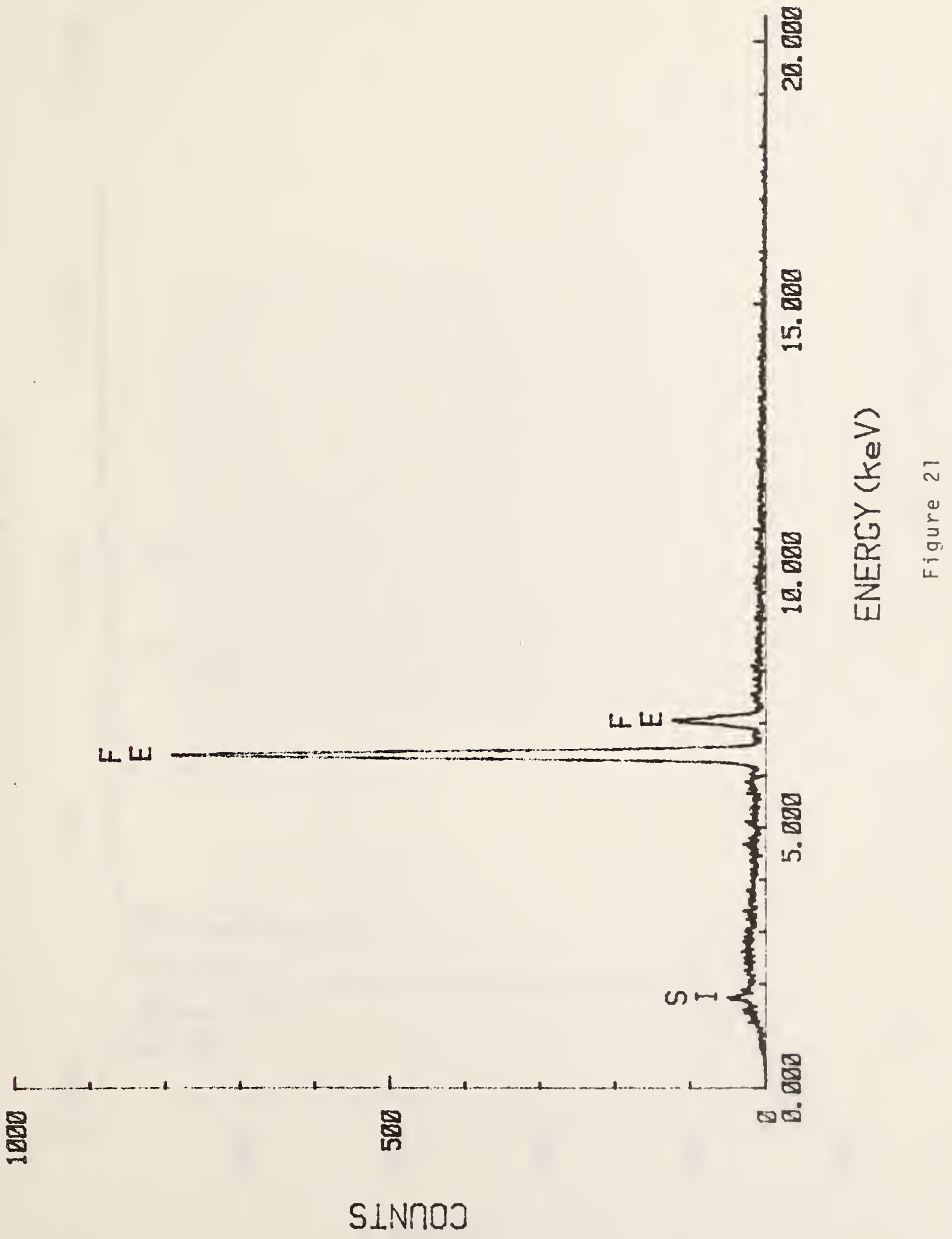




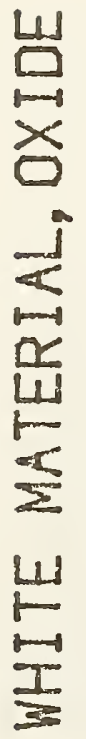

崩

$\stackrel{\sim}{N}$

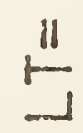

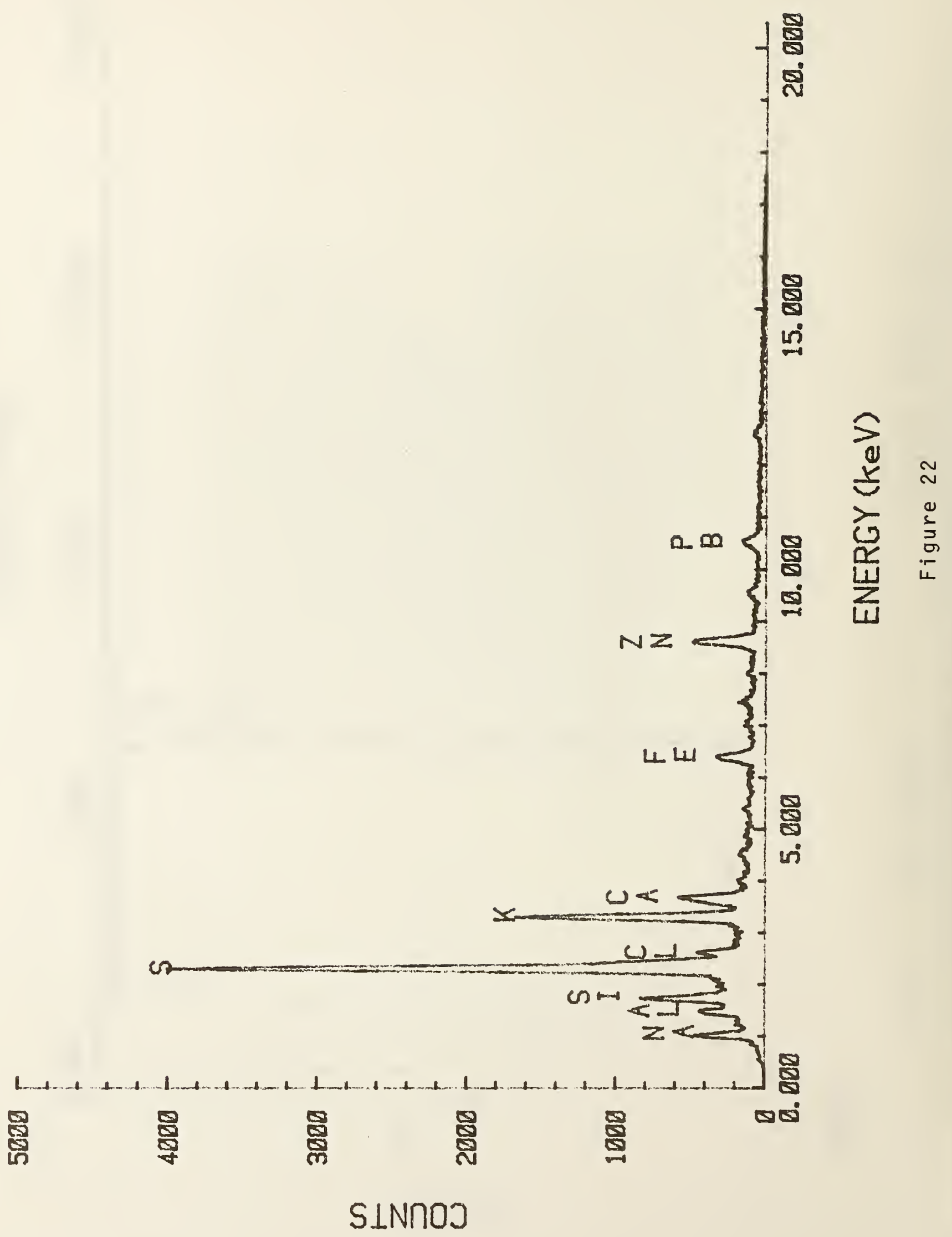



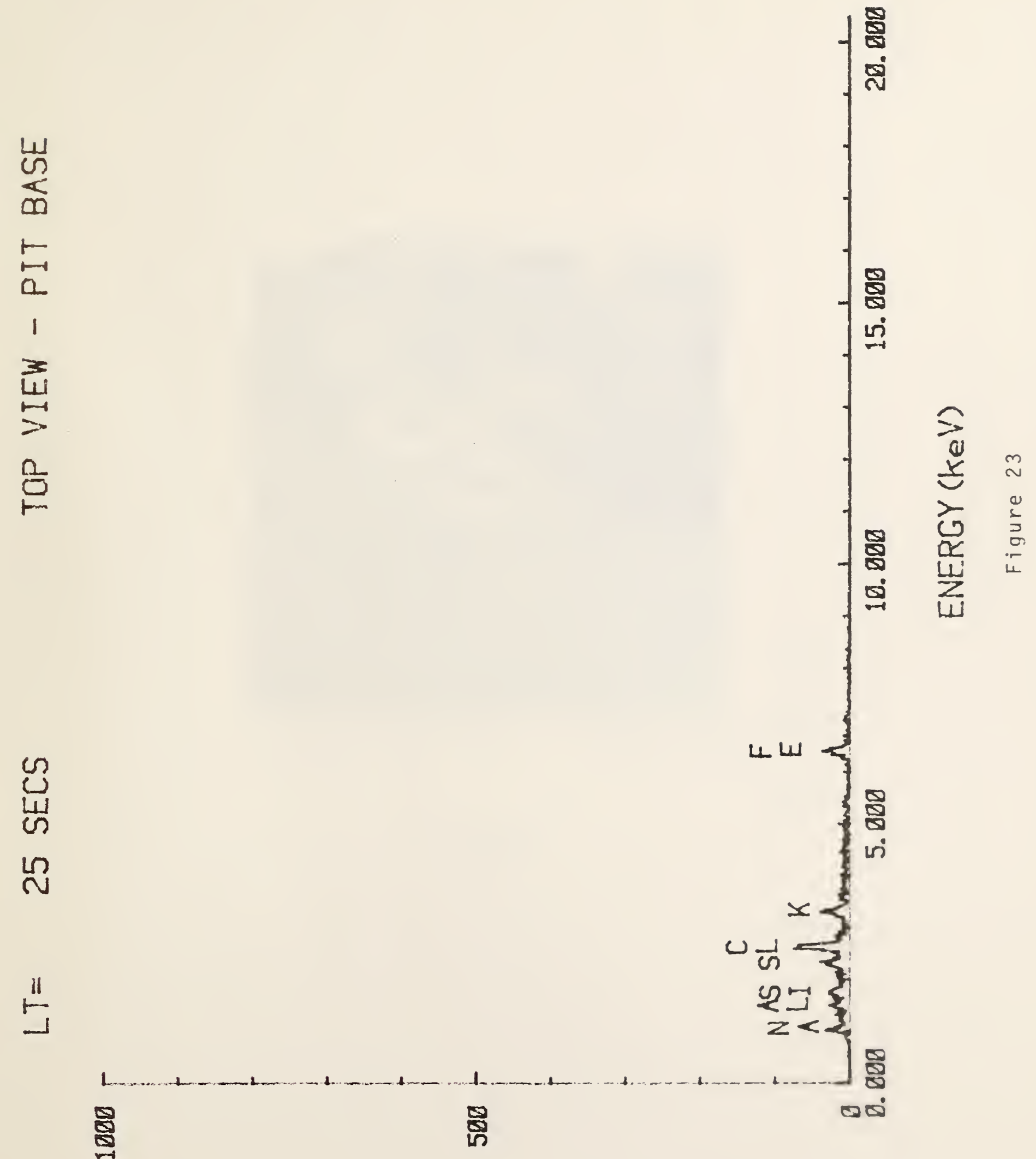

出

고

$\stackrel{1}{\leftrightarrows}$

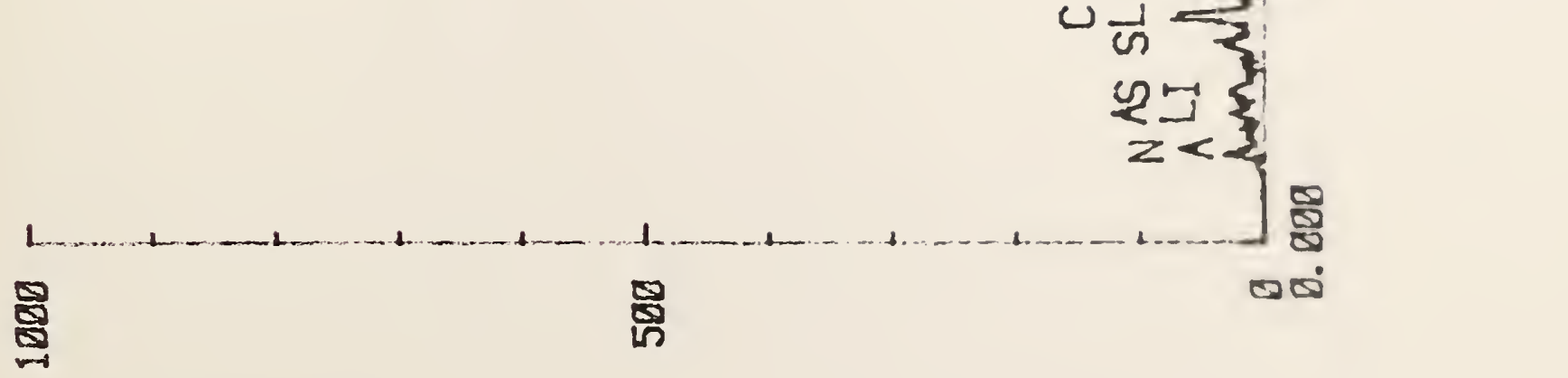

SinnoJ 


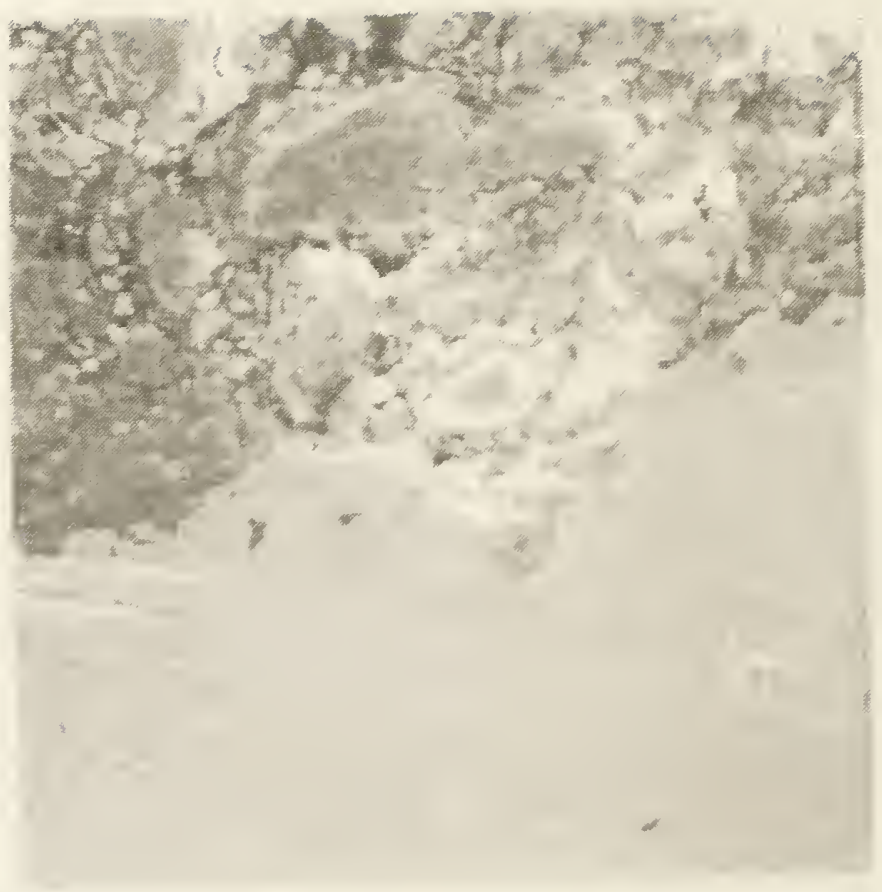

Fiqure 24 
$\frac{1}{a}$
$\leftarrow$
$a$

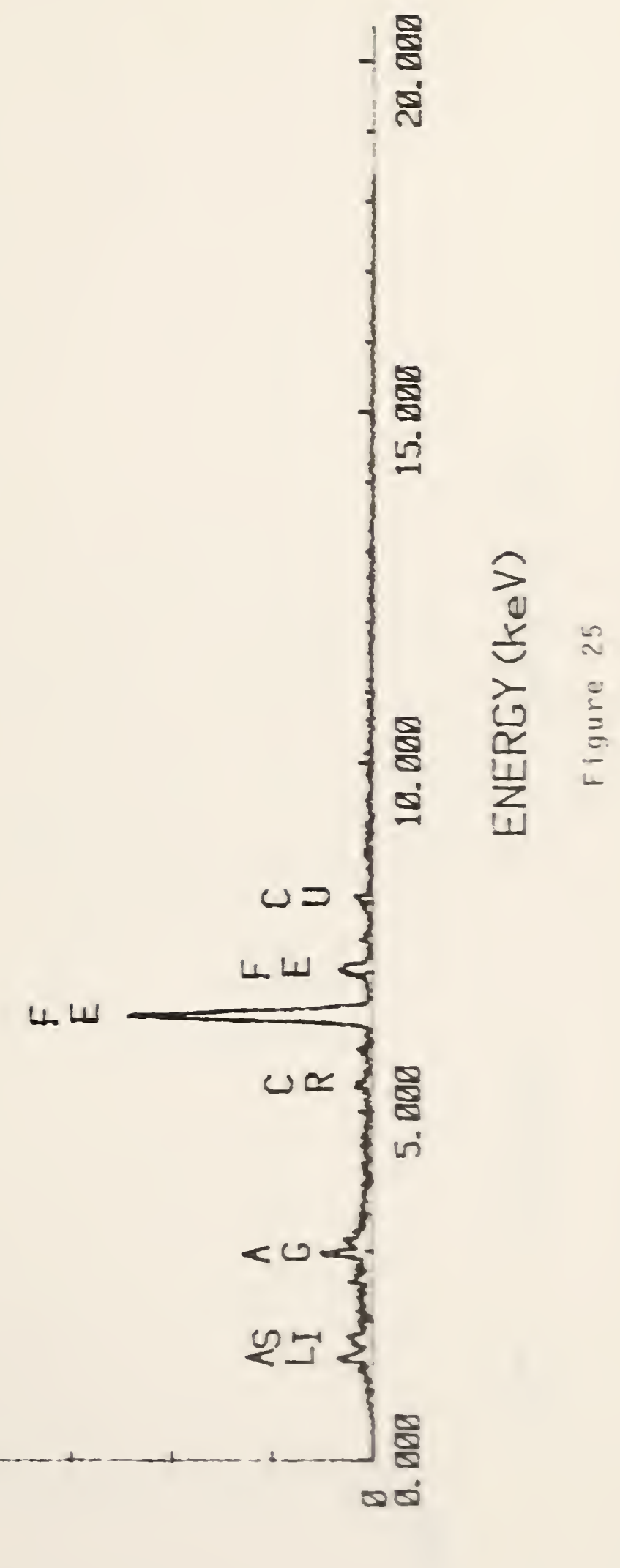

SINnOJ 


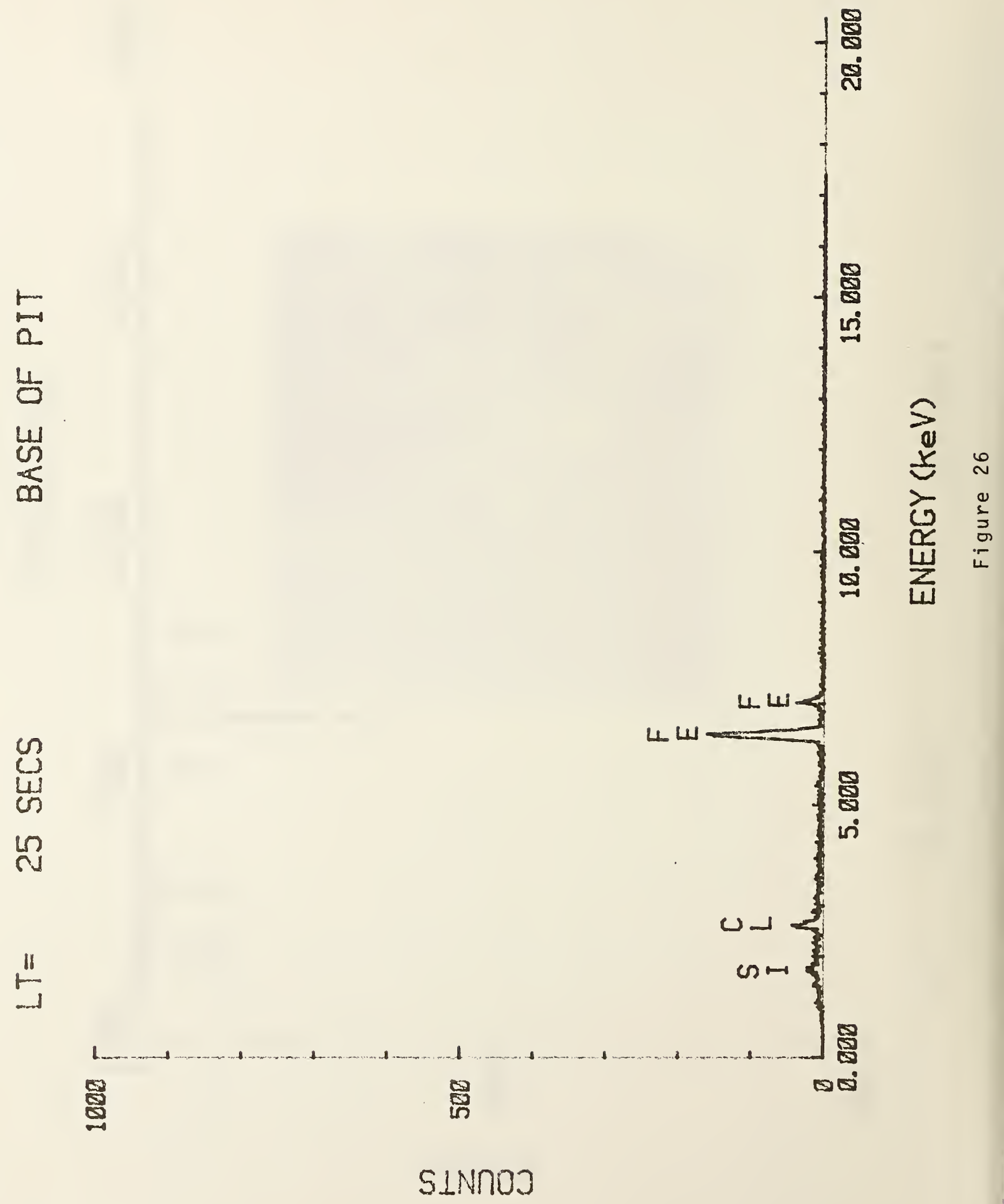




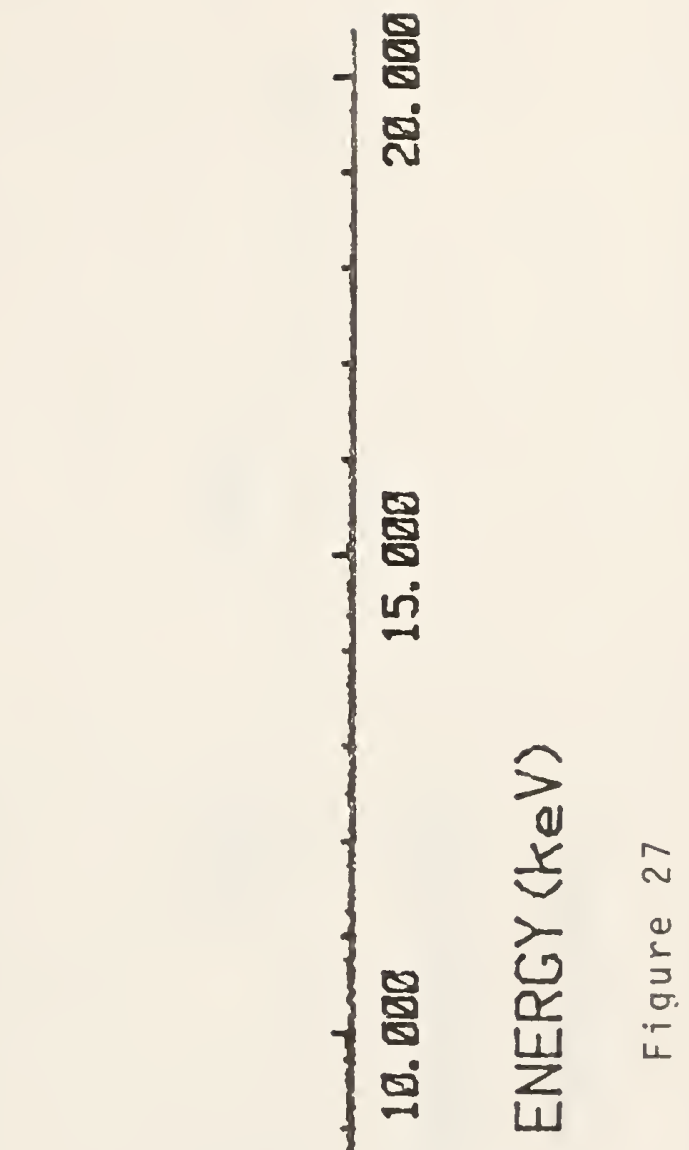

总

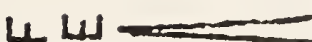

น

II

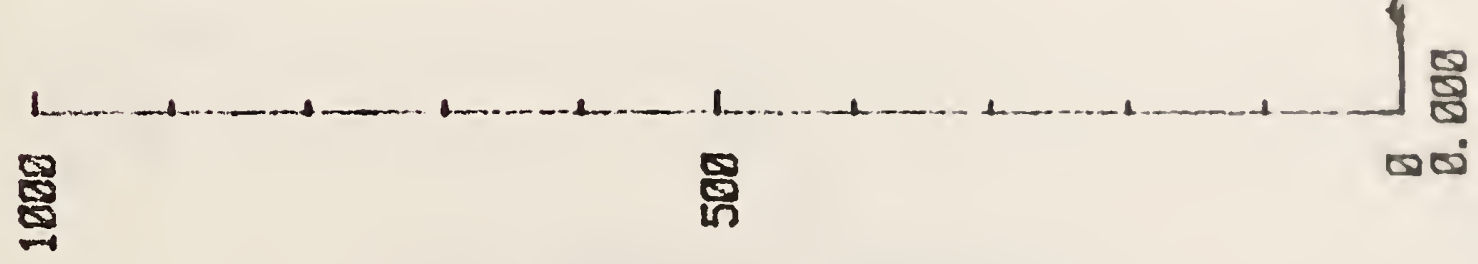

SINNOJ 
吝

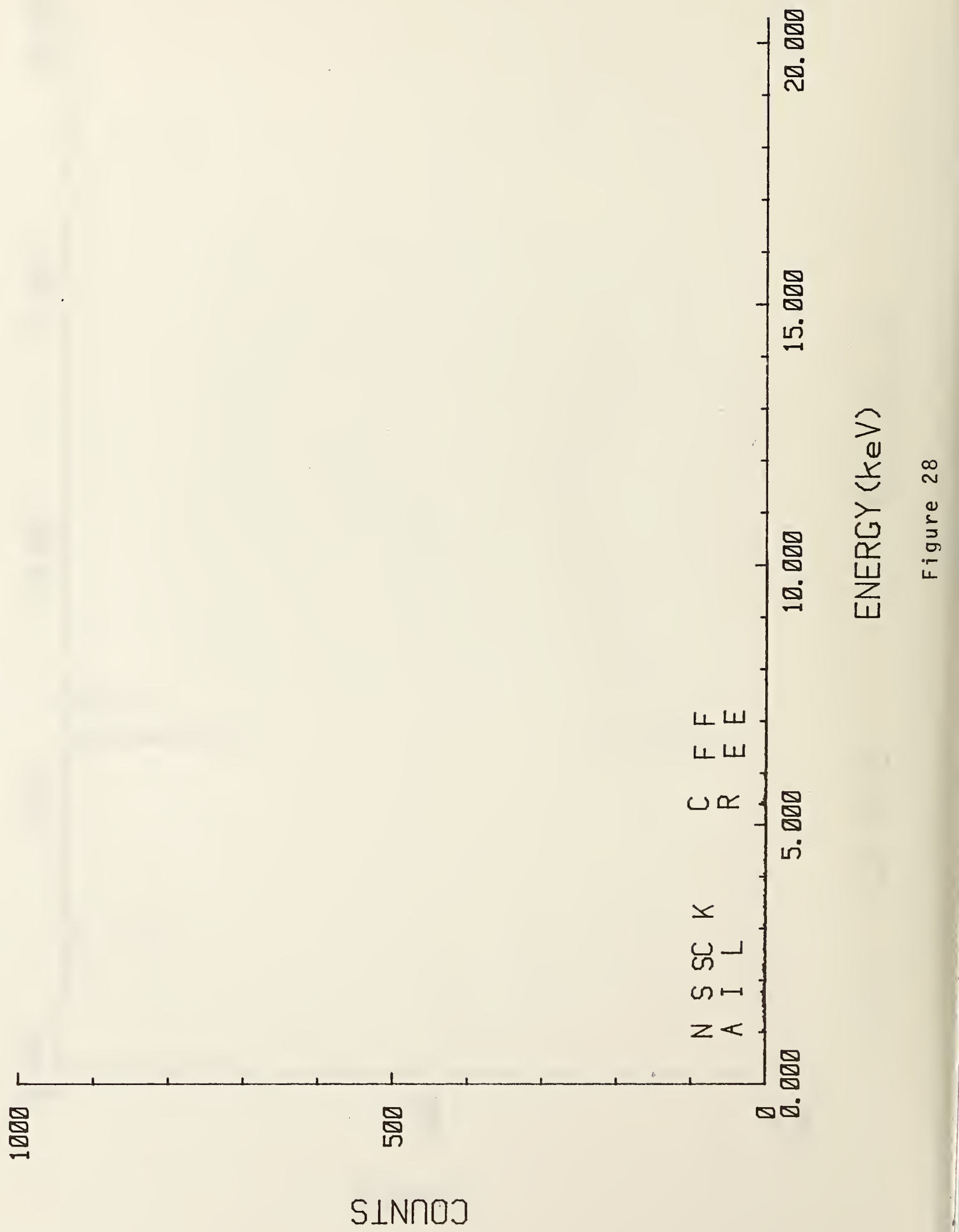




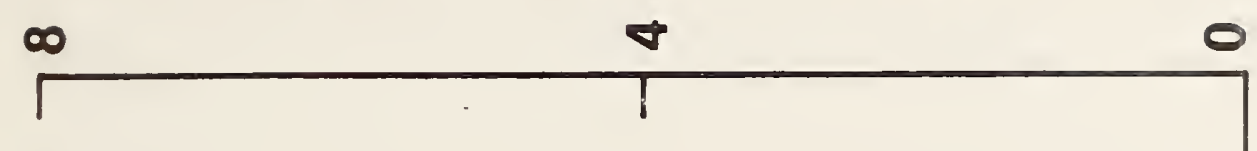

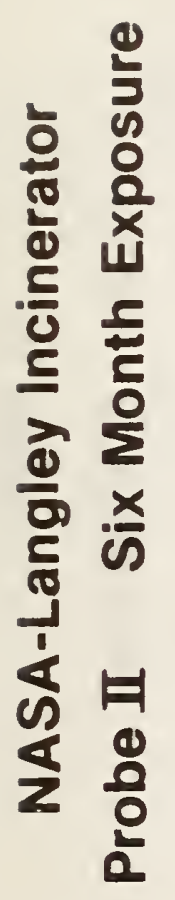

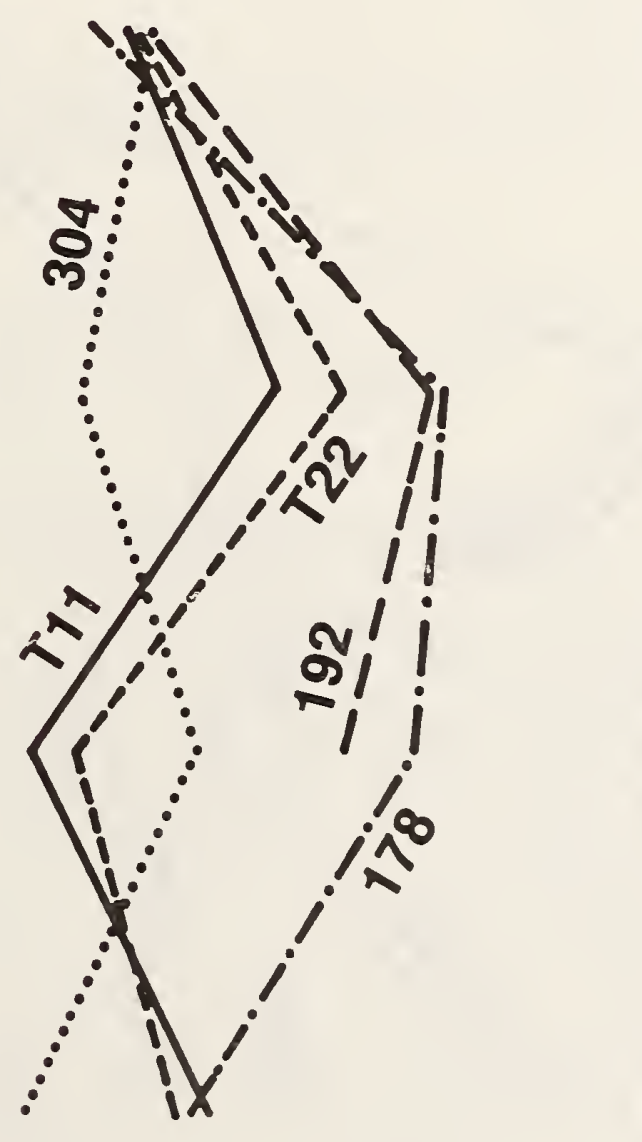

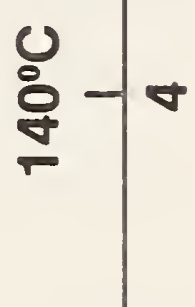

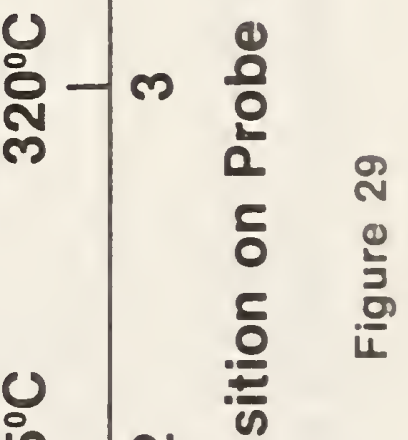

\&

\&

in- $N$ a

$\begin{aligned} & 0 \\ & 0 \\ & \infty\end{aligned}-$

wn 'yłdəa 1!d unu!xew 
s!!u 'ułdəa H!d unu!xeW
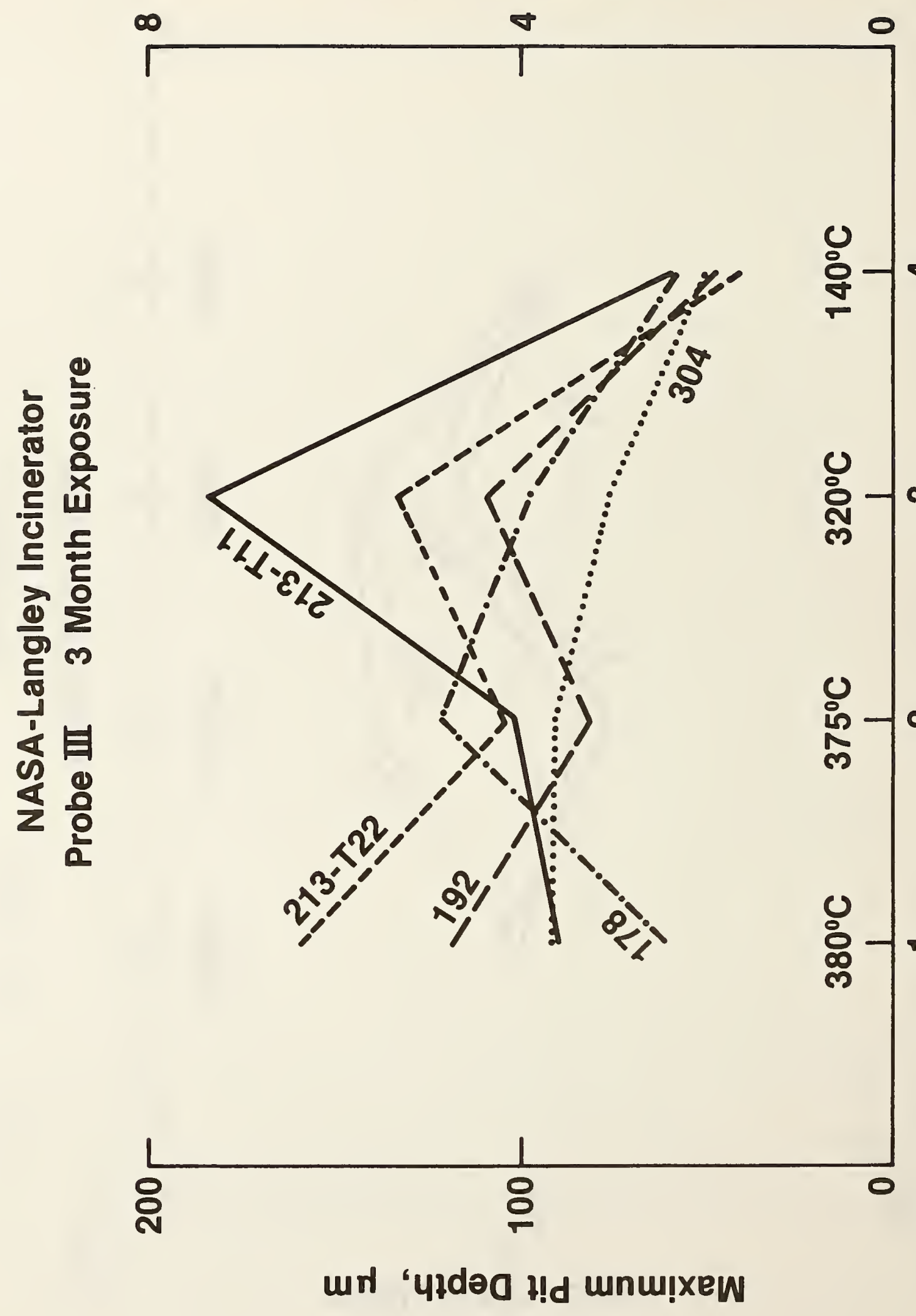
BIBLIOGRAPHIC DATA

SHEET (See in structions)

NBSIR $\quad 84-2959$

2. Performing Organ. Report Nof 3. Publication Date

October 1984

4. TITLE AND SUBTITLE

Corrosion of Materials Used in Steam Generating Boiler Systems

5. AUTHOR(S)

E. Escalante, D. Mathews, J. Fink

6. PERFORMING ORGANIZATION (If joint or other than NBS, see instructions)

NATIONAL BUREAU OF STANDARDS

DEPARTMENT OF COMMERCE

\begin{tabular}{l|l} 
WASHINGTON, D.C. 20234 & Final Report
\end{tabular}

7. Contract/Grant No.

DOE EA-77-A-01-6010

9. SPONSORING ORGANIZATIONA NAME AND COMPLETE ADDRESS (Street, CIty, Stote, ZIP\})

U. S. Department of Energy

1000 Independence Ave., SW

Washington, DC 20585

10. SUPPLEMENTARY NOTES

Document describes a computer program; SF-185, FIPS Software Summary, is attached.

11. ABSTRACT (A 200-word or less foctual summory of most significant information. If document includes o slgnificont bibliogrophy or literoture survey, mention it here)

Five alloys, SA178, SA192, SA213-T11, SA213-T22, and Type 304 stainless steel, were evaluated on their resistance to pitting in a coal burning boiler and in a residential refuse burning incinerator. The materials were introduced into the vicinity of the boiler tubes using a probe whose temperature was controlled and monitored to simulate conditions of the boiler tubes. After three to six months, the probes were withdrawn and the alloy specimens removed for evaluation. The data indicate that the environment of the refuse burning incinerator was considerably more aggressive than that of the coal burning boiler. Chloride was found in practically all the pits examined in the alloys from the refuse burning system, but no chloride was found in the pits examined on the materials exposed in the coal burning boiler. The data suggest that the moisture from lawn clippings increases the rate of attack which is further aggravated by large temperature fluctuations. Type 304 stainless steel was the most resistant to pitting in both environments, but the SA213-T11 and SA213-T22 were lesS resistant to pitting than the lower alloy SAl78 and SAl92 in the refuse burning incinerator.

12. KEY WORDS (Six to twelve entries: olphobeticol order: copitalize only proper names; ond seporoce key words by semicolons) chloride attack, coal burning boiler; corrosion probe; moisture effect; municipal solid waste burning incinerator; pitting corrosion; refuse burning; stainless steel; steam boiler; temperature effect.

13. AVAILABILITY

[X] Unlimited

For Official Distribution. Do Not Release to NTIS

Order From Superintendent of Documents, U.S. Government Printing Office, Washington, D.C. 20402.

14. NO. OF PRINTED PAGES

51

15. Price

$[X]$ Order From National Technical Information Service (NTIS), Springfield, VA. 2216I 


